\title{
¿SOLO POR LEY NACE LA OBLIGACIÓN INDEMNIZATORIA DE DERECHO PÚBLICO? NOTAS SOBRE LA INDEMNIZACIÓN DE DERECHO PÚBLICO DESDE LA PERSPECTIVA DEL ORDENAMIENTO ESPAÑOL*
}

\section{Carlos Céspedes Muñoz**}

RESUMEN: En línea de principio, la indemnización surgida como consecuencia de la realización de una actuación ajustada a derecho por parte de un ente público, solo tiene lugar cuando la ley la ordene expresamente. Esta idea se ha robustecido con el nacimiento del concepto de ley en el sistema del moderno Estado de Derecho, establecida como una norma general que permite diferenciar entre las regulaciones limitadoras de carácter general en el ordenamiento social de los bienes de aquellas intervenciones especiales en el mismo. El objetivo del presente trabajo consiste en determinar si esa premisa se aplica al sistema español, en que el fenómeno expansivo de la responsabilidad patrimonial de la Administración y de la responsabilidad del Estado legislador parecen seńalar otros rumbos.

PALABRAS CLAVE: Indemnización; Derecho público; Ley; Responsabilidad Administración.

\section{IS COMPENSATORY DUTY OF PUBLIC LAW JUST BORN BY LAW? NOTES ON COMPENSATION OF PUBLIC LAW FROM THE PERSPECTIVE OF SPANISH ORDER}

ABSTRACT: As a matter of principle, the compensation arised as a result of performing a correct action by a legal public body, only takes place when the law expressly ordered it. This idea has been strengthened with the arising concept of law within the system of modern rule of law, which was established as a general rule to differentiate between the limi-

Fecha de recepción: 12 de julio de 2016.

Fecha de aceptación: 1 de marzo de 2017.

** Doctor en Derecho por la Universidad de Salamanca (España). Profesor de Derecho Civil de la Universidad Católica de la Santísima Concepción (Chile). Correo electrónico: ccespedes@ucsc.cl. 
ting general regulations in the social order of the assets of those special interventions itself. The aim of this study is to determine if that premise is actually applied to the Spanish legal system, in which the expanding phenomenon of Administration's patrimonial liability and the legal responsibility of the State legislature seem to set out in other directions.

KEY WORDS: Compensation; Public law; Law; Liability; Administration.

Sumario: Palabras previas. 1) Breves notas sobre el origen y evolución de la indemnización de Derecho público. 2) Teorías sobre el fundamento de la indemnización de Derecho público. 3) Por regla general, el Estado solo tiene la obligación de indemnizar en virtud de una ley que asi lo ordene expresamente. 4) La responsabilidad patrimonial de la Administración. (4.1.) La teoría de la indemnización como instituto distinto de la responsabilidad patrimonial de la Administración. (4.2.) Las criticas de Fernando Pantaleón. (4.3.) Las críticas de Oriol Mir. (4.4.) La respuesta a las críticas por parte de Eduardo García de Enterría. (4.5.) La tesis de Francisco Javier de Ahumada Ramos. (4.6.) Corolario. 5) La responsabilidad del Estado legislador. (5.1.) Actos legislativos de naturaleza expropiatoria y aquellos que no lo son. (5.2.) Actos legislativos de naturaleza no expropiatoria. (5.2.1.) Indemnización de los perjuicios ocasionados por una ley declarada inconstitucional. (5.2.2.) Indemnización de los perjuicios ocasionados por la vulneración del Derecho Comunitario. (5.2.3.) Indemnización de los perjuicios ocasionados por la vulneración del principio de confianza legitima. (5.3.) Calificación de una ley de naturaleza expropiatoria y corolario. Conclusiones. Bibliografía citada.

\section{Palabras PReVias}

En tiempos en que los derechos de los ciudadanos se han ido ampliando profusamente, la circunstancia de que aquellos sean completamente "indemnizados" por las agresiones lícitas e ilícitas que puedan sufrir en su patrimonio, ha traído como consecuencia un aumento de los conceptos por los cuales el Estado debe reparar el daño causado a los particulares.

En este sentido, la denominada responsabilidad del Estado se ha erigido como un sector del Derecho rico en nuevos planteamientos y desafíos, cuyas notas esenciales queremos develar en el presente estudio. 
Para efectos de su análisis nos hemos situado desde el ordenamiento español, en donde el sistema reparatorio estatal es tan extenso que permite indemnizar no solo el daño causado ilícitamente, sino también lícitamente. Y que tiene nuevas leyes vigentes sobre la materia desde el 2 de octubre de 2016 (39/2015, sobre Procedimiento Administrativo Común de las Administraciones Públicas, y 40/2015, de Régimen Jurídico del Sector Público).

\section{1) BREVES NOTAS SOBRE EL ORIGEN Y EVOLUCIÓN DE LA INDEMNIZACIÓN DE DERECHO PÚBLICO}

Que el Estado deba responder por los daños causados por sus órganos no fue una conclusión necesaria ni evidente ab initio. Y que deba reparar los daños originados en el ejercicio legítimo de sus potestades públicas, menos.

En un primer momento se imponía la completa irresponsabilidad del Estado y de sus agentes por los actos del Poder, graficándose tal situación en el brocardo anglosajón "the King can do not wrong". Luego, con la aceptación de los principios del Estado de Derecho y la separación de los poderes, se comenzó incipientemente a admitir una cierta responsabilidad, imputándose esta exclusivamente a los agentes del Estado ${ }^{2}$, para, posteriormente, admitir la responsabilidad de estos con el Estado ${ }^{3}$ y, finalmente, una responsabilidad directa y objetiva de este ${ }^{4}{ }^{5}$.

Tal evolución, propia de la responsabilidad extracontractual del Estado, también podemos predicarla respecto de la actuación legítima de la Administración que ocasiona un daño. Pero, ¿por qué el Estado debe

1 Garrido Falla, Fernando (1997) "Los límites de la responsabilidad patrimonial: una propuesta de reforma legislativa". Revista española de Derecho administrativo, No 94, pp. 173-188, p. 175; Marienhoff, Miguel (1992) "Responsabilidad del Estado por sus actos lícitos". En U. Complutense (editor). Actualidad y perspectivas del Derecho público a fines del siglo XX. Homenaje al profesor Garrido Falla, vol. II. Madrid: Editorial Complutense, pp. 1247-1262, p. 1249.

2 Marienhoff (I992) 1249.

3 Garrido (1997) 176; Marienhoff (1992) 1249.

4 Garrido (1997) 176; Marienhoff (1992) 1249. Sobre responsabilidad directa y objetiva de la Administración Pública, entre otros, González Pérez, Jesús (2006) Responsabilidad patrimonial de las Administraciones Públicas. 4a edición. Cizur Menor: Thomson Civitas, 734 p., pp. 201 y ss.

5 La evolución específica en el sistema español puede verse en García de ENTERría, Eduardo (1955) "Potestad expropiatoria y garantía patrimonial en la nueva Ley de Expropiación Forzosa”. Anuario de Derecho Civil. Vol. 8, N 5, pp. 1023-1166, pp. 1104 a 1116. 
reparar los daños causados en el recto ejercicio de una potestad pública? ¿Cuál es el fundamento de esta indemnización?

Estas interrogantes nos llevan a estudiar el origen y causa de la denominada "indemnización de Derecho público"6, que comprende a aquellas indemnizaciones concedidas a un particular por las intervenciones inferidas a su patrimonio por la Administración conforme a Derecho ${ }^{7}$ y que, según algunos, permite diferenciarla de la responsabilidad por acto ilícito ${ }^{8}$.

Su nacimiento se sitúa en la época absolutista del ejercicio del ius eminens, el que, sin embargo, no impedía a los súbditos reclamar la respectiva indemnización cuando existían afectaciones a sus derechos adquiridos ${ }^{9}$. Esta misma solución se impuso, incluso, cuando se sustituyó la doctrina del ius eminens por el Estado-policía, que autorizaba al Príncipe para intervenir en la vida jurídica y económica del país en virtud de una amplia cura promovendi salutis: los derechos adquiridos, a diferencia de los derechos naturales, no se aportan a la comunidad social, por lo que si el soberano decide intervenir en ellos, es obligado a indemnizar ${ }^{10}$. Con el surgimiento del Estado de Derecho y la consecuente protección de los derechos del ciudadano, las intromisiones estatales sobre el patrimonio de los particulares siguieron planteando la interrogante de determinar si estas traían aparejada o no la indemnización de los perjuicios ocasionados por el ejercicio legítimo del poder público.

Se ha señalado que el deber de indemnización por parte de la Administración reconoce dogmáticamente las siguientes fases ideales: a) como reflejo de una intervención administrativa en los derechos adquiridos; b) cuando la intervención se realiza por medio de un acto individual que

Denominación utilizada por FleINer, Fritz (1933) Instituciones de Derecho administrativo. Traducción de la $8^{a}$ edición alemana por Sabino A. Gendin. Barcelona-Madrid-Buenos Aires: Editorial Labor S.A., 362 pp., pp. 233 y ss.; Garrido Falla, Fernando (1952) "La teoría de la indemnización en Derecho público". En Estudios dedicados al profesor Gascón y Marin. Madrid: Instituto de Estudios de Administración Local, pp. 411-443, pp. 411 y ss.; Forsthoff, Ernst (1958) Tratado de Derecho administrativo. Madrid: Instituto de Estudios Políticos, 768 p., pp. 426 y ss.

7 Fleiner (1933) 235; Garrido Falla (1952) 422; Forsthoff (1958) 426 y ss.

8 Alessi, Renato (1939) La responsabilità della pubblica amministrazione, vol. I. Milán: Giuffrè, 275 p., p. 244, nota 2 parte final; Garrido Falla, Fernando (i988) Tratado de Derecho Administrativo, vol. II. $8^{a}$ edición. Madrid, Tecnos, 420 p., p. 220; González Pérez (2006) 190. En contra, Mir Puigpelat, Oriol (2002) La responsabilidad patrimonial de la Administración. Hacia un nuevo sistema. Madrid: Civitas, 371 p., p. 123)”. Forsthoff (1958) 426; Nieto, Alejandro (1962) "Evolución expansiva del concepto de la expropiación forzosa”. Revista de Administración Pública, N³8, pp. 67-124, pp. 70 y 71. zación de la responsabilidad patrimonial del Estado". Revista de Administración Pública, $\mathrm{N}^{\circ}$ 119 , pp. $7-48$, p. 9. 
produce un sacrificio desigual; c) cuando, introduciendo el elemento de la ilicitud o culpabilidad, el deber de indemnización se canaliza a través de dos vías: por actos lícitos (teoría de la indemnización de Derecho público) y por actos ilícitos (teoría de la responsabilidad); d) cuando, eliminando el concepto de falta o ilicitud, se asiste a un proceso reunificador a través de las siguientes vías: o bien mediante una expansión del instituto de la expropiación, que absorbe a todas o casi todas las demás figuras generadores del deber de indemnizar, o bien, a través de la formación de una base dogmática genérica: la lesión ${ }^{11}$.

Como afirmaba Forsthoff, esta indemnización de Derecho público se erigió como un anexo problemático de la expropiación ${ }^{12}$. Lo anterior, porque la expropiación representa el caso más importante de las intromisiones públicas del Estado, aunque no el único, puesto que ellas fueron aumentando a medida que se extendieron las funciones de aquel ${ }^{13}$.

\section{2) TEORÍAS SOBRE EL FUNDAMENTO DE LA INDEMNIZACIÓN DE DERECHO PÚBLICO}

La primera teoría que se enarboló fue la de la inviolabilidad de los derechos adquiridos (ius quaesitum) ${ }^{14}$, en virtud del cual el Estado debe indemnizar cuando anule o limite un derecho individual al cual le fue concedido una fuerza especial contra las intervenciones estatales ${ }^{15}$. Estos derechos pertenecen definitivamente al patrimonio de las personas favorecidas -como los derechos de propiedad industrial, de pesca o aprovechamiento de aguas concedidos en anteriores períodos del desenvolvimiento jurídico $^{16}$-, por lo que nadie puede ser privado de ellos sino mediante la respectiva indemnización ${ }^{17}$.

Una segunda tesis, fundada en la garantía constitucional del derecho de propiedad, sostiene que el Estado debe indemnizar no solo en los casos en que se prive del dominio a un particular mediante el mecanismo de la expropiación forzosa, sino, en general, por todo perjuicio que un acto de

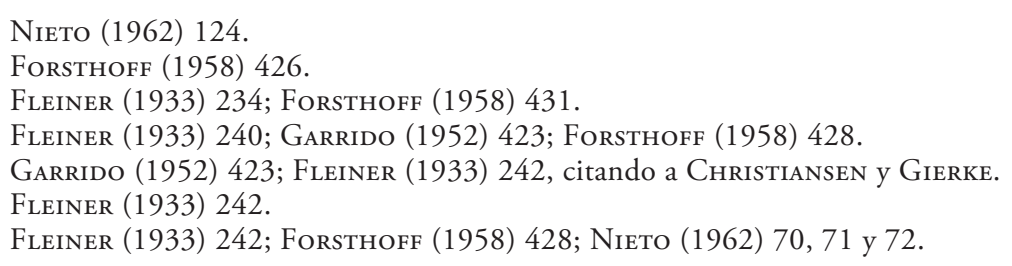


autoridad ocasione en el patrimonio de los ciudadanos ${ }^{18}$. Todo desconocimiento de la propiedad que no respete los principios inspiradores de la expropiación es intolerable en un Estado moderno, imponiéndose como regla general la indemnización ${ }^{19}$.

Basándose en el principio de la igualdad jurídica y constitucional de los ciudadanos ante las cargas públicas ${ }^{20}$, una tercera opinión sostiene que el Estado debe indemnizar al particular por todo sacrificio especial que se le imponga, es decir, por toda restricción impuesta que exceda de la medida general ${ }^{21}$. Esta posición se basó en la interpretación efectuada por los comentaristas alemanes a la Constitución de Weimar, por la cual entendieron por expropiación a "todo perjuicio causado al patrimonio privado por la ley o un acto administrativo que, en beneficio de la generalidad, imponga gravámenes especiales a determinadas personas o a un conjunto de individuos relativamente limitados, siendo indiferente que con esto se origine un traspaso de objetos o derechos y que se refieran o no a un fin de utilidad pública"22.

Finalmente, una cuarta posición propone que el Estado solo tiene la obligación de indemnizar en todos aquellos casos en que la ley o un derecho consuetudinario así lo ordenen expresamente ${ }^{23}$.

Podrá apreciarse que estas teorías presentan como denominador común la circunstancia de hacer procedente la indemnización solo para casos especiales, pues no puede sostenerse como regla general que cualquier daño que sufra un particular a causa de los actos legales del Estado deba ser reparado ${ }^{24}$. El problema es que las tres primeras tesis sujetan el

Fleiner (1933) 240 y 241; Garrido Falla, Fernando, Palomar Olmeda, Alberto y LoSAdA GonzÁlez, Herminio (2006). Tratado de Derecho Administrativo. 12a edición, vol. II. Madrid: Tecnos, 592 p., p. 318.

GARRIDO (1952) 423.

Garrido (1952) 424.

FLEINER (1933) 241.

Fleiner (1933) 241. Textualmente lo sigue Garrido (1952) 424. En opinión de FORSTHOFF, esta idea se materializó en los parágrafos 74 y 75 de la introducción al Landrecht prusiano: "\$74. Los derechos particulares y las ventajas de los miembros del Estado tienen que posponerse a los derechos y deberes necesarios al fomento del bien común, cuando entre ellos existe una contradicción (colisión) real. S 75. Sin embargo, el Estado queda obligado a indemnizar a aquellos cuyos derechos particulares y ventajas se ha visto precisado a sacrificar al bien de la comunidad (ForsthofF (1958) 428 y 429)".

Fleiner (1933) 241.

Este razonamiento lo comparte, en sede de responsabilidad patrimonial de las Administraciones públicas: Pantaleón Prieto, Fernando (1994) "Los anteojos del civilista: hacia una revisión del régimen de responsabilidad patrimonial de las Administraciones públicas". Revista Documentación Administrativa, No 237-238, pp. 239-254, p. 245; reiterado en PANTAleón Prieto, Fernando (1995) Responsabilidad médica y responsabilidad de la Administración (hacia una revisión del sistema de responsabilidad patrimonial de las Administraciones Públicas). Madrid: Civitas, 91 p., pp. 73 y 74 ). 
fundamento de la obligación reparatoria a fórmulas generales ${ }^{25}$, de difícil concreción.

Así, a la teoría de los derechos adquiridos se le critica que su posición se ve debilitada en los Estados de Derecho modernos, en donde existen instituciones que protegen al ciudadano de las arbitrariedades e ilegalidades de las autoridades administrativas, privando de un amplio campo a las demandas indemnizatorias por violación de derechos adquiridos ${ }^{26}$. Recordemos que esta tesis tuvo aplicación en el Estado-policía, persiguiendo proteger al súbdito del soberano absoluto en aquellos tiempos en que no había garantías contra las limitaciones arbitrarias de la propiedad y la libertad $^{27}$.

Por otro lado, esta tesis, en su intento de reconocer el derecho a una indemnización por razones de equidad, llegó a considerar como derechos lo que no era más que meros intereses ${ }^{28}$. Y existe consenso en la doctrina de que el objeto del sacrificio que da lugar a una reparación debe ser un verdadero derecho, excluyendo a las meras expectativas o simples intere$\operatorname{ses}^{29}$.

Asimismo, la tesis que obliga a reparar todo perjuicio que un acto de autoridad ocasione en el patrimonio de los ciudadanos, en los hechos haría indemnizable cualquier daño que sufra el particular, desconociendo que no todo perjuicio imputable a la Administración es indemnizable ${ }^{30}$. Por lo demás, provocaría la paralización de las actividades administrativas, por temor a incurrir en hechos generadores de reparación ${ }^{31}$.

Tampoco la tesis del sacrificio especial sirve como fundamento indiscutible de la obligación del Estado de indemnizar por los daños causados en su actuación legítima. Se ha sostenido que cada nueva actividad de la

Fleiner (1933) 242.

Fleiner (1933) 242.

Fleiner (1933) 242 y 243; Garrido Falla (1952) 423.

Fleiner (1933) 243.

Forsthoff (1958) 449 y ss.; Garrido (i988) 230 y 231; De Ahumada distingue entre "intereses legítimos" y los "simples intereses legítimos", que son "aquellos intereses que, siendo en sí mismo lícitos, por no ser contrarios al ordenamiento jurídico... sin embargo, su satisfacción no es exigible frente al sujeto que causa el daño al bien objeto de interés..." (DE Ahumada Ramos, Francisco Javier (2004) La responsabilidad patrimonial de las Administraciones públicas. 2a edición. Cizur Menor: Thomson Aranzadi, 587 p., p. 169).

30 De Ahumada (2004) 60. Pareciere ser el mismo razonamiento de Garrido, al sostener que los casos de indemnizaciones exigen una interpretación restrictiva, a diferencia de los supuestos de responsabilidad como consecuencia de la ilegalidad de un acto estatal, en que el principio debe ser el de que siempre que se causa un daño este debe repararse (GARRIDo (1952) 428).

31 Aplicamos similar argumento que el indicado por García de ENTERRÍA para imputar responsabilidad directa a la Administración y no al funcionario (GARCía de Enterría (1955) 1114). 
Administración genera perjuicios y ventajas desiguales a las diferentes clases de ciudadanos ${ }^{32}$. Más aún, la configuración de los presupuestos para reparar esta clase de daños tampoco permite dar claridad a este tema.

En efecto, según Blasco Esteve, "... cuando la actuación administrativa es conforme a Derecho, el concepto legal de lesión se concreta fundamentalmente en el sacrificio especialmente grave e intenso: si se da este, no hay causas de justificación del daño y, por consiguiente, el perjudicado no tiene el deber de soportarlo..."33. Pues bien, conforme a tal autor, tratándose del ejercicio legítimo de una potestad administrativa, lo que habría que analizar es cómo se configura dicha potestad en el caso concreto: si el resultado dañoso se impone como querido expresamente, el perjuicio está justificado; en los demás casos, no se descarta la procedencia de responsabilidad, debiendo investigarse un criterio material de fondo en el caso específico $^{34}$. Lo anterior lleva consigo una completa incertidumbre, pues la obligación indemnizatoria no se produce a todo evento y nos pone en la encrucijada de ir determinando caso a caso qué daño es importante y qué daño no, para luego establecer la procedencia de su reparación ${ }^{35}$. Por ello, se ha afirmado que esta tesis no aporta criterios para poder distinguir qué perjuicios deben indemnizarse y cuáles no, ni tampoco entrega elementos para alcanzar la justicia del caso concreto ${ }^{36}$, además de generar inseguridad jurídica ${ }^{37}$.

\section{3) Por regla general, El Estado solo tiene la obligación DE INDEMNIZAR EN VIRTUD DE UNA LEY QUE ASÍ LO ORDENE EXPRESAMENTE}

Como principio, el Estado solo tiene la obligación de indemnizar en todos aquellos casos en que la ley así lo ordene expresamente. De esta manera, la única tesis que no tiene reparos sobre el particular es aquella que ubica el origen de la obligación indemnizatoria por actuación legítima de la Administración solo en la ley"38.

FLeINER (1933) 243.

Blasco Esteve, Andrés (1981) La responsabilidad de la Administración por actos administrativos. Madrid: Civitas, 243 p., pp. 200 y ss.

BLASCO (1981) 189.

De Ahumada (2004) 83 y ss.

De Ahumada (2004) 87.

Blasco (1981) 189; De Ahumada (2004) 87.

Fleiner (1933) 244. De ahí la interpretación extensiva del artículo 42.2 de la Constitución italiana que propone Alessi, a objeto de considerar incorporado en el concepto de propiedad no solo a los derechos reales sino también, en general, a los derechos patrimoniales 
Y esta es la doctrina que asumió nuestra Excma. Corte Suprema explícitamente desde la sentencia "Inmobiliaria Maullín Ltda. con Fisco de Chile" 39 (con su antecedente "Sociedad Agrícola Lolco Ltda. con Fisco de Chile" 40 y cambiando el parecer manifestado en "Comunidad Galletué con Fisco de Chile" $\left.{ }^{41}\right)^{42}$, en virtud de la cual solo procede la concesión de una indemnización por acto lícito en virtud de una norma legal que la contemple expresamente ${ }^{43}$.

La admisión de esta tesis se ha facilitado con el nacimiento del concepto de ley en el sistema del moderno Estado de Derecho, establecida como una norma general que permite diferenciar entre las regulaciones limitadoras de carácter general en el ordenamiento social de los bienes de aquellas intervenciones especiales en el mismo ${ }^{44}$.

Esta distinción se aprecia con toda claridad en la regulación específica que se hace de la expropiación en los distintos ordenamientos, por constituir el caso de principal aplicación de las indemnizaciones a las que nos estamos refiriendo, que solo es procedente en virtud de una ley que así la determine. Como también lo evidencia la figura alemana de la "delimitación de derechos necesitada de compensación” (ausgleichspflichtige Inhaltsbestimmung), por la cual cuando una regulación legal limita la propiedad de una forma general ajustada a la Constitución, pero genera cargas especiales injustificables e inexigibles desde la óptica de los principios

de las personas, infiriendo, con ello, el principio de intangibilidad del patrimonio (Alessi (1939) 253 y ss.).

Corte Suprema. 5 de octubre de 2010. Rol No 552-2008. "Inmobiliaria Maullín Ltda. con Fisco de Chile". Disponible en www.poderjudicial.cl [fecha de visita: 16 de junio de 2015]. Corte Suprema. 30 de diciembre de 2004. Rol No 381-2004. "Sociedad Agrícola Lolco Ltda. con Fisco de Chile". Disponible en www.poderjudicial.cl [fecha de visita: 16 de junio de 2015].

41 Corte Suprema. 7 de agosto de 1984. Rol N 16.743-1983. "Comunidad Galletué con Fisco de Chile”. Disponible en www.westlawchile.cl, CL/JUR/2/1984 [fecha de visita: 16 de junio de 2015].

42 El impacto de la doctrina Galletué puede examinarse en Oelckers Camus, Osvaldo (1987) "Fundamentos indemnizatorios en razón del acto administrativo lícito que cause daño en el patrimonio del administrado". Revista de Derecho de la Pontificia U. Católica de Valparaíso, № 11, pp. 67-77; y en Cordero Quinzacara, Eduardo (2006) "La dogmática constitucional de la propiedad en el Derecho chileno". Revista de Derecho (Valdivia), vol. XIX, N 1, pp. 125-148. La evolución de la jurisprudencia de la Excma. Corte Suprema puede revisarse en Cordero Vega, Luis (2011) "La Corte Suprema y la responsabilidad del Estado". El Mercurio Legal, 20 de septiembre de 2011. Disponible en www.elmercurio.com [fecha de visita: 16 de junio de 2015]; y en Cordero Vega, Luis (2012). "Las vacas locas y la responsabilidad del Estado por acto lícito". El Mercurio Legal, 22 de noviembre de 2012. Disponible en www.elmercurio.com [fecha de visita: 16 de junio de 2015]. responsabilidad estatal por actos lícitos. El ocaso de la doctrina Galletué". Revista de Derecho del Consejo de Defensa del Estado, $\mathrm{N}^{\circ} 12$, pp. 41-54. Forsthoff (1958) 429. 
de proporcionalidad o igualdad, debe ser objeto de una compensación económica establecida en la propia ley, ya que sin ella tal normativa sería inconstitucional ${ }^{45}$.

No obstante, en el ámbito del Derecho administrativo español esta conclusión se ve desbordada frente al concepto amplísimo de "lesión" que utiliza la doctrina dominante para referirse a la responsabilidad patrimonial de la Administración, que hace resarcible a todo perjuicio antijurídico que sufra el particular, no porque la conducta del autor sea contraria a Derecho, sino porque el sujeto que lo sufre no tiene el deber jurídico de soportarlo ${ }^{46}$. Por lo tanto, para estos efectos, no hay diferencia si la indemnización se debe a una actuación lícita o ilícita de la Administración ${ }^{47}$, como pasaremos seguidamente a comentar.

Otro tanto ocurren en el ordenamiento alemán con la creación jurisprudencial de la figura del "ataque o intervención expropiatorio" (enteignender Eingriff), que surgió para indemnizar aquellos daños colaterales sobre la propiedad, generalmente atípicos e imprevisibles, que se derivan de actuaciones de la Administración ajustadas a Derecho y que representan para el particular un sacrificio superior al que le es obligado soportar ${ }^{48}$.

En otras palabras, fuera del ámbito de los daños antijurídicos (en que su resarcimiento parece natural), analizaremos si es decisiva o no la existencia de una ley que ordene el pago de la respectiva indemnización cuando en virtud del legítimo ejercicio de una potestad pública se concretan intervenciones en el patrimonio de los particulares. Para tal fin, estudiaremos dos sectores en que se configura una amplia gama de indemnizaciones de Derecho público por actuaciones ajustadas a Derecho en el sistema espańol: la responsabilidad patrimonial de la Administración y la responsabilidad del Estado legislador.

\section{4) LA RESPONSABILIDAD PATRIMONIAL DE LA ADMINISTRACIÓN}

Para la doctrina y jurisprudencia tradicional ${ }^{49}$, por regla general, son indemnizables todos los dańos causados por la Administración que los

Mir (2002) 114

García de Enterría (1955) 1125. Dan cuenta de este concepto amplio: GonzÁLez (2006)

191; De Ahumada (2004) 58 y ss.

García de Enterría (1955) 1124.

Mir (2002) 80.

Que no puede considerarse dominante después de la crítica efectuada por Pantaleón (1994) 245; Pantaleón (1995) 73 y 74; y seguida por numerosos otros autores, según Mir Puigpelat, Oriol (2004) "El sistema español de responsabilidad patrimonial de la Adminis- 
particulares no tengan el deber jurídico de soportar de acuerdo con la ley. Esta tesis sobre el instituto de la responsabilidad patrimonial de la Administración, construida principalmente a partir de la relación de los artículos $9.3^{50}, 106.2^{51}$ y $149.1 .18^{52}$ de la Constitución espańola (CE); y de los artículos $32.1^{53}$ y $34.1^{54}$ de la recién entrada en vigencia Ley $40 / 2015^{55}$, de Régimen Jurídico del Sector Público (LRJSP), consagra un concepto de responsabilidad por el cual la Administración responde por los daños causados tanto por su actuación lícita como ilícita ${ }^{56}$; y de forma objetiva: no se exige la concurrencia de dolo o culpa para exigir dicha responsabi$\operatorname{lidad}^{57}$. Debe dejarse constancia que la última de las leyes citadas no ha modificado sustancialmente el estatuto de responsabilidad patrimonial regulado en su momento por la Ley 30/1992, sobre Régimen Jurídico de

tración: una visión crítica”. En Marín González, Juan Carlos (compilación y estudio introductorio). La responsabilidad patrimonial del Estado. Ciudad de México: Editorial PorrúaItam, pp. 1-51, p. 36.

50 "La Constitución garantiza el principio de legalidad, la jerarquía normativa, la publicidad de las normas, la irretroactividad de las disposiciones sancionadoras no favorables o restrictivas de derechos individuales, la seguridad juridica, la responsabilidad y la interdicción de la arbitrariedad de los poderes públicos".

51 "Los particulares, en los términos establecidos por la ley, tendrán derecho a ser indemnizados por toda lesión que sufran en cualquiera de sus bienes y derechos, salvo en los casos de fuerza mayor, siempre que la lesión sea consecuencia del funcionamiento de los servicios públicos".

52 "El Estado tiene competencia exclusiva sobre las siguientes materias: 18. Las bases del régimen jurídico de las Administraciones públicas y del régimen estatutario de sus funcionarios que, en todo caso, garantizarán a los administrados un tratamiento común ante ellas; el procedimiento administrativo común, sin perjuicio de las especialidades derivadas de la organización propia de las Comunidades Autónomas; legislación sobre expropiación forzosa; legislación básica sobre contratos y concesiones administrativas y el sistema de responsabilidad de todas las Administraciones públicas".

53 "Los particulares tendrán derecho a ser indemnizados por las Administraciones Públicas correspondientes, de toda lesión que sufran en cualquiera de sus bienes y derechos, siempre que la lesión sea consecuencia del funcionamiento normal o anormal de los servicios públicos salvo en los casos de fuerza mayor o de daños que el particular tenga el deber juridico de soportar de acuerdo con la Ley".

54 "Solo serán indemnizables las lesiones producidas al particular provenientes de daños que este no tenga el deber jurídico de soportar de acuerdo con la Ley. No serán indemnizables los daños que se deriven de hechos o circunstancias que no se hubiesen podido prever o evitar según el estado de los conocimientos de la ciencia o de la técnica existentes en el momento de producción de aquellos, todo ello sin perjuicio de las prestaciones asistenciales o económicas que las leyes puedan establecer para estos casos".

55 Debe dejarse constancia que el 2 de octubre de 2016 entraron en vigor la Ley 39/2015, de 1 de octubre, sobre Procedimiento Administrativo Común de las Administraciones Públicas (LPCAP), y la Ley 40/2015, de 1 de octubre, sobre Régimen Jurídico del Sector Público (LRJSP). Mayores antecedentes sobre la LPCAP pueden consultarse en GozÁlbez PequeNo, Humberto (director) (2016) La nueva Ley del Procedimiento Administrativo Común. Madrid: El Consultor de los Ayuntamientos-Wolters Kluwer.

56 García de Enterría (1955) 1124; González (2006) 191 y 203; Garrido (1988) 220, nota 7; De Ahumada (2004) 58 y ss.

57 González-Varas, Santiago (2012) Tratado de Derecho administrativo. 2a edición. Tomo I. Cizur Menor: Civitas-Thomson Reuters, 856 p., p. 514. 
las Administraciones Públicas y Procedimiento Administrativo Común (LRJPAC); por lo que las explicaciones que daremos, fundadas en la antigua normativa, sirven perfectamente para la nueva ${ }^{58}$.

Esta opinión, dotada de fundamento teórico por García de EnTERRÍA ${ }^{59}$ y cuya base normativa inicial encontraba sustento en los artículos 121.1 de la Ley Expropiación Forzosa (LEF) ${ }^{60}$ y 40 de la Ley de Régimen Jurídico de la Administración del Estado (LRJAE) ${ }^{61}$ de 1957, se desprendía del tenor literal de la primera de las disposiciones nombradas: la Administración debe responder de toda lesión que "sea consecuencia del funcionamiento normal o anormal de los servicios públicos”. Con lo cual la reparación podía emanar de una actuación regular o irregular, lícita o ilícita ${ }^{62}$. Así las cosas, este instituto resarcitorio operaría como mecanismo de indemnización de todo daño, salvo que exista una causa de justificación que legitime el respectivo perjuicio ${ }^{63}$.

En el mismo sentido también se ha pronunciado buena parte de la jurisprudencia, destacando por la amplitud y extensión asignada a la responsabilidad patrimonial de la Administración la comentada sentencia del Tribunal Supremo de 14 de junio de $1991^{64}$, que condenó a INSALUD por los dańos sufridos por una paciente como consecuencia de una intervención quirúrgica impecable desde el punto de vista de la lex

58 En este sentido, Pizarro Nevado, Rafael (2016) "Capítulo I. Disposiciones generales, principios de actuación y funcionamiento del sector público". En Gozálbez Pequeño, Humberto (director). El nuevo régimen jurídico del sector público. Madrid: El Consultor de los Ayuntamientos-Wolters Kluwer, pp. 15-152, p. 102.

Así lo consigan Garrido (1997) 185; De Ahumada (2004) 58 y ss.

"Dará también lugar a indemnización con arreglo al mismo procedimiento toda lesión que los particulares sufran en los bienes y derechos a que esta Ley se refiere, siempre que aquella sea consecuencia del funcionamiento normal o anormal de los servicios públicos, o la adopción de medidas de carácter discrecional no fiscalizables en vía contenciosa, sin perjuicio de las responsabilidades que la Administración pueda exigir de sus funcionarios con tal motivo".

61 "Los particulares tendrán derecho a ser indemnizados por el Estado de toda lesión que sufran en cualquiera de sus bienes y derechos, salvo en los casos de fuerza mayor, siempre que aquella lesión sea consecuencia del funcionamiento normal o anormal de los servicios públicos o de la adopción de medidas no fiscalizables en vía contenciosa".

62 García de Enterría (1955) 1124; Bello Janeiro, Domingo (2006) "La responsabilidad patrimonial de la Administración". Revista Práctica de Derecho de Daños, No 37, La Ley 517/2006. Disponible en www.laleydigital.es [fecha de visita: 4 de agosto de 2012], p. 1-14, p. 10.

García de Enterría (1955) 1126; Leguina Villa, Jesús (1983) La responsabilidad civil de la Administración Pública. 2a edición. Madrid: Tecnos, 374 p., p. 169. Mir es elocuente sobre el carácter objetivo de esta clase de responsabilidad, afirmando que la regla es la obligación de indemnizar y la exoneración la excepción (Mir (2004) 15).

RJ 1991/5115. 
$\operatorname{artis}^{65}$. En el mismo sentido, las sentencias del Tribunal Supremo de 4 de abril de $2000^{66}$ y de 6 de marzo de $2000^{67}$.

Lo anterior tiene su antecedente en la construcción unitaria de la responsabilidad patrimonial de la Administración y del instituto de la expropiación forzosa sobre el concepto unificador de "lesión que no hay deber jurídico de soportar" ${ }^{68}$; y se justifica en el carácter objetivo de esta clase de responsabilidad, que nace al margen de toda idea de culpa o ilegalidad $^{69}$, siendo determinante la existencia de la antijuridicidad del resultado o lesión ${ }^{70}$.

Sin perjuicio de lo anterior, para que ello tenga lugar deben concurrir los siguientes requisitos materiales para hacer surgir la responsabilidad patrimonial de la Administración: a) que la víctima sufra un daño efectivo, evaluable económicamente e individualizado con relación a una persona o grupo de personas (artículo 32.2 LRJSP) que no tenga el deber jurídico de soportar de acuerdo con la ley y que no derive de hechos o circunstancias imprevisibles o inevitables según el estado de los conocimientos de la ciencia o de la técnica existentes en el momento de su pro-

65 Que condenó a INSALUD por los daños sufridos por una paciente como consecuencia de una intervención quirúrgica impecable desde el punto de vista de la lex artis, indemnización que no habría tenido lugar si el hospital hubiese sido de propiedad privada. Lo que llevó a Pantaleón a afirmar que “... no veo ninguna razón convincente para conceder a doña María Teresa esos más de diez millones de indemnización cuando no se le conceden a quien resulte igualmente incapacitado a causa de un desafortunado resbalón en la bañera... (Pantaleón (1994) 244 y 245, reiterada en Pantaleón (1995) 75)".

RJ 2000/3258.

67 RJ 2000/2600.

68 García de Enterría (1955) 1124 y ss. Y la crítica de Pantaleón: “... ha llegado el momento de abandonar esa cautivadora obra de imaginación juridica que fue la construcción unitaria de la responsabilidad patrimonial de la Administración y del instituto de la expropiación forzosa sobre el concepto de lesión que no hay deber de soportar: entre la responsabilidad por lo que hemos llamado "daños cuasiexpropiatorios", de evidente conexión con la expropiación forzosa, y la responsabilidad por riesgo existe una profunda sima principial" (Pantaleón (1994) 253; PANTALEÓN (1995) 90 y 91).

69 Entre varios, GonZÁlez-Varas (2012) 514; García de Enterría (1955) 1125; González (2006) 203 y ss.; De Ahumada (2004) 55 y ss.; Garrido (1988) 153 y ss.; Leguina Villa (ig83) 169 y ss.; Berberoff Ayuda, Dimitry y Sospedra Nava, Francisco (2006). Fundamentos dogmáticos de la responsabilidad patrimonial de la Administración en la jurisprudencia, vol. II. Madrid: Consejo General del Poder Judicial-Fundación Wellington, 463 p., pp. 63 y ss.; Moreno Molina, José Antonio y Magán Perales, José María (2005). La responsabilidad patrimonial de las Administraciones Públicas y, en especial, de las Corporaciones Locales. Madrid: Editorial El Consultor de los Ayuntamientos y de los Juzgados, 663 p., pp. 30 y ss. En sentido similar, STS de 26 de mayo de 2010 (RJ 2010/5421).

70 En este sentido, STS de 3 de mayo de 2012 (La Ley 56859/2012). Asimismo, entre varios, García de Enterría (1955) 1125; Leguina (1983) 169; González-Varas (2012) 514516; Rodríguez Carbajo, José Ramón (2010). "La antijuridicidad del daño como requisito de la responsabilidad patrimonial de la Administración". Actualidad Administrativa, No 7, La Ley 1812/2010. Disponible en www.laleydigital.es [fecha de visita: 25 de julio de 2012], pp. 1-8, pp. 1 y 2. 
ducción (artículo 34.1 LRJSP); b) que dicho daño sea consecuencia del funcionamiento normal o anormal de los servicios públicos (artículo 32.1 LRJSP); y, c) que dicho daño no sea imputable a fuerza mayor (artículo 32.1 LRJSP $^{71}$.

En base a lo antes expuesto, se han clasificado los distintos títulos de reparación por parte de la Administración de la siguiente forma ${ }^{72}$ : a) responsabilidad por actuación culpable o negligente de la Administración, que comprende a la responsabilidad por actos administrativos ilegales y por funcionamiento anormal del servicio; y, b) responsabilidad objetiva sin culpa, que integra a los supuestos de responsabilidad por actos administrativos válidos; por funcionamiento normal del servicio, por creación de situaciones de riesgo y de actos no fiscalizables (no anulables) en vía contenciosa.

Pues bien, esta configuración amplia del sistema de responsabilidad patrimonial de la Administración -que hace indemnizable todo daño que el particular no esté obligado a soportar porque no existe un título justificativo que así lo disponga-, ha conducido, según algunos, a la consagración de un sistema basado en la seguridad social más que en un carácter resarcitorio $^{73}$. Lo que ha llevado a sostener que este sistema presenta como principales defectos "su excesiva amplitud, su excesiva indeterminación y su excesiva uniformidad"74.

Esta anterior constatación ha llevado a algunos a criticar la reforma efectuada al sector público por la Ley 40/2015 (LRJSP): “... la LRJSP se limita a asumir la regulación de la LRJPAC ańadiendo algunas novedades de escasa relevancia, por lo que también en esta materia se ha dejado pasar la ocasión de dar respuesta a las propuestas doctrinales para corregir las carencias de la legislación vigente y reducir de ese modo la inseguridad jurídica y el protagonismo judicial en la aplicación del sistema"75.

Es por ello que desde un inicio y, al menos doctrinariamente, se han formulado observaciones a la configuración del sistema de la responsabilidad patrimonial de la Administración, como pasamos a anotar. Frente al amplio concepto que sigue la doctrina y jurisprudencia tradicional, se han

71 Bajo el amparo de la antigua ley, no modificada por la actual, se pronunciaba así MiR (2004) p. 3. Más sintéticamente, también bajo el vigor de la anterior normativa, se han señalado los siguientes: a) que se haya producido la lesión de un derecho o bien jurídicamente protegido de una persona o grupo de personas; $y, b)$ que exista un nexo de causalidad entre dicha lesión y el funcionamiento de los servicios públicos (De Ahumada (2004) 148).

72 Según Garrido, Palomar y Losada (2006) 339 y ss.

73 Pantaleón (1994) p. 250, reiterada en Pantaleón (1995) 85; De Ahumada (2004) 135.

74 Mir Puigpelat (2004) 4 y ss. Como lo grafica la STS de 14 de junio de 1991 (RJ $1991 / 5115)$, antes reseñada.

75 Pizarro Nevado (2016), 102. 
enarbolado una serie de teorías que propugnan un concepto más restringido de la responsabilidad de la Administración, a saber:

\section{(4.1.) LA TEORÍA DE LA INDEMNIZACIÓN COMO INSTITUTO DISTINTO DE LA RESPONSABILIDAD PATRIMONIAL DE LA ADMINISTRACIÓN}

El profesor Garrido Falla, incluso desde antes de la entrada en vigencia de la Ley de Expropiación Forzosa ${ }^{76}$, instaba por la separación de los institutos de la responsabilidad y de la indemnización. Así, la responsabilidad patrimonial de la Administración surgiría como consecuencia de la actividad ilícita administrativa o dentro del campo de los dańos causados sin título jurídico para ello; y la teoría de la indemnización tendría su lugar en el campo de la actividad administrativa lícita ${ }^{77}$. Esta distinción se desprendería de la propia CE, que regula a la indemnización en su artículo 33.3 y a la responsabilidad en su artículo $106.2^{78}$.

Señala que, históricamente, la actual teoría de la responsabilidad patrimonial de la Administración tuvo su origen en el reconocimiento y posterior expansión del instituto de la indemnización expropiatoria, no obstante lo cual su desarrollo autónomo fue advertido y explicado por la doctrina ${ }^{79}$. Así, en el sistema alemán, Forsthoff enseñaba que las indemnizaciones en casos de intervenciones soberanas en la ordenación de los bienes son distintas en su fundamento jurídico y peculiaridad, según que la intervención sea conforme a Derecho o antijurídica ${ }^{80}$. Y Alessi, en Italia, evidenciaba que la indemnización de los dańos por actividad legítima tenía un fundamento teórico y positivo distinto de la normal responsabilidad, al punto de indicar que a la primera impropiamente se le llamaba responsabilità ${ }^{81}$.

Afirma que la teoría de la indemnización postula un fundamento propio, el cual sería la igualdad de todos los ciudadanos ante las cargas públicas que hace odioso el sacrificio especial sin indemnización. Y que se fortalece cuando el sacrificio del derecho del particular determina una transferencia coactiva de propiedad a favor de la Administración, pues

\footnotetext{
76 En su artículo del año 1952 "La teoría de la indemnización en Derecho público”, ya citado.

77 GARRIDO (1988) 220.

78 GARRIDO (1997) 177.

79 Garrido, Palomar y Losada (2006) 319.

80 ForsthofF (1958) 413.

81 Alessi (1939) 244.
} 
aquí se une otro fundamento: el enriquecimiento sin causa a favor de aquella $^{82}$.

La importancia de la distinción de las causas generadores de la obligación de indemnizar a que puede estar sujeta la Administración -actuaciones lícitas o ilícitas-, implica reconocer diversos requisitos de procedencia y la distinta medida de la indemnización, dado que están informados por distintos principios ${ }^{83}$.

En efecto, tratándose de la indemnización expropiatoria, habría que probar el enriquecimiento patrimonial o la ventaja directa conseguida para el interés público; $y$, en los supuestos de responsabilidad en sentido estricto, debería probarse la forma como el funcionamiento normal o anormal del servicio ha determinado el daño sufrido ${ }^{84}$. Y, en cuanto a la medida del resarcimiento, en la indemnización expropiatoria solo debería repararse el daño emergente pero nunca el lucro cesante ${ }^{85}$, a diferencia de la responsabilidad propiamente tal, en que se impone el principio de reparación integral del daño ${ }^{86}$.

\section{(4.2.) LaS CRíticas de Fernando Pantaleón}

Considerando la tesis de Garrido Falla ${ }^{87}$, Pantaleón Prieto también ha manifestado sus críticas a la configuración del sistema de responsabilidad patrimonial de la Administración. Afirma que su régimen legal está mal concebido, tanto desde la perspectiva dogmática -porque no hay base jurídica para sostener que todo daño que el perjudicado no tenga el deber de soportar debe ser indemnizado por quien lo causa- como desde el prisma de la política jurídica: "un Derecho razonable no debe parificar, no debe estimar regidos por los mismos principios jurídicos el caso en que alguien pierde su coche porque la Administración se lo expropia, o porque la policia lo destruye por sospechar que unos terroristas lo habian cargado con un artefacto a punto de explosionar, y el caso en que alguien pierde su coche al estrellarlo contra un árbol que se habia caido sobre la calzada unos minutos antes" 88 .

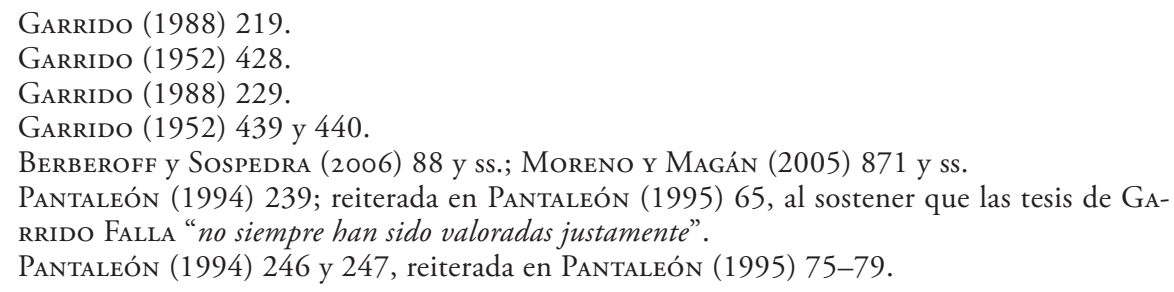


Por lo anterior, propone considerar los siguientes supuestos: a) responsabilidad por funcionamiento normal de los servicios públicos; $\mathrm{y}, \mathrm{b}$ ) responsabilidad por dańos producto de accidentes ${ }^{89}$.

El primer supuesto comprende a los daños que propone llamar como "cuasi expropiatorios o de sacrificio", "entendiendo por tales aquellos que son (producto indeseado, pero) consecuencia inmediata o directa de actuaciones administrativas lícitas de las que los daños aparecen como secuela connatural, como realización de un potencial dañoso intrínseco a la actuación administrativa en cuestión; siendo también necesario, obvio es, que los daños de que se trate representen para quien los padece un sacrificio individualizado que no le sea exigible soportar" 90 . Respecto de estos daños por funcionamiento normal de los servicios, responderán en todo caso las Administraciones públicas al amparo del actual artículo 32.1 LRJSP ${ }^{91}$.

El segundo supuesto comprende a los dańos producto de accidentes, que serían aquellos "en cuya etiología aparezca implicada, ciertamente, la actividad típica de una Administración Pública, pero que no sean consecuencia de una medida finalmente dirigida causar, ni connatural, intrinseca o inmediatamente... los daños infligido" " 92 . En este caso, las Administraciones públicas solo responderán: a) de los daños derivados de fautes de service, como consecuencia del funcionamiento anormal de los servicios públicos ex artículo 32.1 LRJSP; y, b) cuando así lo dispongan leyes especiales, sin necesidad de faute, respecto de los daños que sean realización de determinados riesgos típicos del giro o tráfico administrativo, que Pantaleón denomina "lesiones consecuencia del funcionamiento de servicios públicos típicamente peligrosos", bajo el estatuto del artículo 32.1 arriba citado, que no excluye ni impone tal resarcimiento ${ }^{93}$.

Con estas precisiones, Pantaleón limita el radio de acción que la doctrina tradicional le ha dado al instituto de la responsabilidad patrimonial de la Administración, ya que, a su juicio, carece de sentido la existencia de un sistema de responsabilidad que cubra todos los riesgos típicos de la gestión pública y que tenga que responder por todos los daños que resulten ser consecuencia directa y adecuada de toda acción u omisión

\footnotetext{
89 Pantaleón (1994) 247 y ss., reiterada en Pantaleón (1995) 81 y ss.

90 Pantaleón (1994) 250, reiterada en Pantaleón (1995) 81 y 82.

91 Bajo el amparo de la antigua normativa, así lo declaraba PANTALEón (1994) 247 y 248, reiterada en PANTAleón (1995) 86.

92 PANTALEÓN (1994) 248, reiterada en PANTALEÓN (1995) 82 y 83.

93 Bajo el amparo de la antigua normativa, así lo declaraba PANTALEÓN (1994) 251, reiterada en PANTALEÓN (1995) 87.
} 
propia del giro administrativo, por la sola circunstancia de que no exista ninguna ley que imponga al perjudicado el deber de soportarlo ${ }^{94}$.

\section{(4.3.) Las CRÍticas de ORIOl Mir}

Quien quizás ha hecho la crítica más profunda al sistema de responsabilidad que nos ocupa es Mir Puigpelat. Afirma que la configuración de este es tan amplia que, "mediando relación de causalidad entre la actuación administrativa y el daño sufrido por la víctima, la regla debe ser el nacimiento de responsabilidad administrativa y su exoneración la excepción"95. Ante tal constatación, propone una reforma que limite la responsabilidad objetiva a supuestos excepcionales y típicos -como los existentes en el Derecho civil- y que erija al funcionamiento anormal de los servicios como el título fundamental de imputación de daños a la Administración. De esta manera, la reforma debería eliminar la genérica referencia al funcionamiento "normal" en el actual artículo 32.1 LRJSP (lo que no hizo la Ley 40/2015), establecer como regla general la indemnización de los daños que deriven solamente del mal funcionamiento de los servicios ${ }^{96} \mathrm{y}$ remitir otros supuestos a determinaciones legales expresas ${ }^{97}$.

Asimismo, sostiene que la responsabilidad patrimonial de la Administración solo cubre los daños derivados incidentalmente de la actuación administrativa y no exigidos directamente por el interés general. Así, se configura como una institución de garantía residual, que opera en defecto de la delimitación de derechos y la expropiación ajustada a Derecho ${ }^{98}$, restringiendo su campo de acción.

En efecto, tratándose de la delimitación de derechos, tanto el legislador como la Administración, al demarcarse normativamente los derechos individuales, quedan sujetos a una serie de restricciones. Dichos límites pueden imponer o no una indemnización, de lo cual se colige que habiéndose previsto o no dicha reparación en la norma delimitadora, habrá existido una decisión referente a la indemnización de los eventuales daños, con lo cual se obligará a la víctima a soportarlos o no conforme al recientemente vigente artículo 34.1 LRJSP99.

\footnotetext{
PANTAleón (1994) 249 y 250, reiterada en PANTALEÓn (1995) 84 y 85.

MIR (2002) 230.

MIR (2004) 34.

Bajo el amparo de la antigua normativa, así lo declaraba MIR (2002) 302 y ss.

MIR (2002) 125 y ss.

Bajo el amparo de la antigua normativa, así lo declaraba MIR (2002) 126.
} 
En cuanto a la expropiación, el justo precio previsto y regulado en la LEF será la única indemnización que percibirá el expropiado, no procediendo cantidad suplementaria alguna a título de responsabilidad extracontractual. Esta exclusión de responsabilidad patrimonial puede fundamentarse en la negación de la existencia del daño o afirmando que el expropiado tiene el deber jurídico de soportarlo ${ }^{100}$.

En todo caso, Mir Puigrelat rechaza la tesis que basa la distinción entre expropiación y responsabilidad en la licitud o ilicitud de la actividad administrativa generadora del daño: la responsabilidad de la Administración puede nacer en ausencia de culpa o antijuridicidad, o sea, en forma objetiva ${ }^{101}$. Con ello, admite la reparación de daños causados lícitamente.

\section{(4.4.) LA RESPUeSta a las CRÍticas POR PARTE de EdUARdo García DE ENTERRÍA}

Frente a las críticas y observaciones de Garrido Falla, Pantaleón Prieto y Mir Puigrelat, García de Enterría -además de admitir que la jurisprudencia ha extendido el ámbito de la responsabilidad en términos que resultan singulares respecto de los demás países occidentales ${ }^{102}$, quizás influida por algunas de sus propias afirmaciones formuladas en términos demasiado rotundos ${ }^{103}$ - sostiene que nunca estuvo en el ánimo de los redactores del artículo 121 LEF (hoy regulado en la LRJSP) consagrar un sistema de responsabilidad objetiva, absoluta y que incluyera supuestos ilimitados de indemnización en cuanto hubiese intervenido un agente público ${ }^{104}$. Por ello, en un intento de restringir el ámbito de aplicación de lo que se ha entendido como responsabilidad patrimonial de la Administración -aunque manteniendo su construcción unitaria con el instituto de la expropiación forzosa bajo el concepto unificador de lesión que no hay deber de soportar-, realiza dos precisiones: la primera, respecto al concepto de "perjuicio antijurídico", y, la segunda, respecto de la concurrencia de alguna causa de imputación.

\footnotetext{
$100 \quad$ MIR (2002) 125 y 126.

101 MIR (2002) 123.

102 GARCÍA DE EnTERría, Eduardo (2002 a) "Prólogo" a la obra de Mir PuigPelat: La responsabilidad patrimonial de la Administración. Hacia un nuevo sistema. Madrid: Civitas, pp. 19-26, p. 20.

103 GARCÍA DE ENTERRÍA (2002 a) 21.

104 GARCÍA DE ENTERRÍA (2002 a) 20 y 21.
} 
Enfatiza que, tal como lo escribió en sus inicios ${ }^{105}$, lo que debe repararse es el perjuicio antijurídico, entendiéndose por tal aquel que el particular no tiene el deber jurídico de soportar. Y, por lo tanto, el avance de la LEF era que desplazaba la nota de antijuridicidad desde la conducta del agente a la perspectiva del patrimonio del dañado ${ }^{106}$. Pero, además, es necesario que concurra alguna causa de imputación, "que no pueden reducirse a un canon unitario" 107 . Reconoce como tales a la realización directa y legítima del daño por la Administración cuando incide sobre un patrimonio que no estaba previamente obligado a soportarlo en sus consecuencias económicas ${ }^{108}$; la actuación ilícita de la Administración, aunque fuese imputable subjetivamente al agente ${ }^{109}$; y los casos de riesgo creado por la Administración ${ }^{110}$. También agregaba en un comienzo al enriquecimiento sin causa de la Administración ${ }^{111}$, lo que el autor ya no considera por objeciones dogmáticas efectuadas a tal criterio ${ }^{112}$, puesto que los institutos de la responsabilidad extracontractual y del enriquecimiento sin causa tienen supuestos de hecho y funciones radicalmente diferentes ${ }^{113}$.

Con estas precisiones, García de Enterría limita el amplísimo concepto atribuido a la responsabilidad patrimonial de la Administración, ya que, de esta forma, no puede concluirse una generalización del sistema de la responsabilidad hacia resultados de una objetivización general de esta $^{114}$.

\section{(4.5.) La tesis de Francisco Javier de Ahumada Ramos}

Compartiendo con García de EnTerría el carácter unitario del sistema de responsabilidad patrimonial de la Administración ${ }^{115}$-pero en un sentido más restringido-, De Ahumada Ramos propone una nueva interpretación del régimen de responsabilidad patrimonial regulado en la LEF

\footnotetext{
105 Refiriéndose, entre otros, a Potestad expropiatoria y garantía extrapatrimonial en la nueva Ley de Expropiación Forzosa, ya citada.

106 GARCÍA DE ENTERría (2002 a) 20 y 21; GARCÍA dE ENTERría (1955) 1125.

107 GARCÍA DE ENTERRÍA (2002 a) 22.

108 García de Enterría (2002 a) 23; García de Enterría (1955) 1146 y 1147.

109 García de Enterría (2002 a) 23; García de Enterría (1955) 1147-1150.

110 García de Enterría (2002 a) 23; García de Enterría (1955) 1150-1153.

111 García de EnTERría (1955) 1153.

112 García de Enterría (2002 a) 23.

113 Pantaleón (1994) p. 250, nota 14.

114 García de Enterría (2002 a) 23.

115 Al descartar el doble fundamento de responsabilidad que propone Garrido Falla: De Ahumada (2004) 92.
} 
y la LRJPAC, contenida esta última en la actualidad en la Ley 40/2015 (LRJSP) ${ }^{116}$. Para él no es un sistema de cobertura de riesgos ni de simples daños que el particular no tenga el deber jurídico de soportar ni tampoco un estatuto fundado en la solidaridad social: "es un sistema de responsabilidad por la lesión de derechos o bienes jurídicamente protegidos, basado en estrictos postulados de justicia conmutativa" 117.

Bajo este prisma, no pertenecerían a este instituto todos aquellos supuestos indemnizatorios que no tengan por fundamento el resarcimiento de un daño antijurídico causado por la Administración, como serían las obligaciones legales de indemnizar cuyos fundamentos se encuentran en la cobertura social de riesgos (accidentes laborales) o en la solidaridad con las víctimas de determinados daños (catástrofes naturales, terrorismo) ${ }^{118}$. Lo anterior implica diferenciar entre el concepto técnico-jurídico de lesión que él propugna -siempre indemnizable- y el de "simple daño" o lesión de "intereses legítimos", que no sería indemnizable bajo el régimen general de responsabilidad patrimonial de la Administración. Además, obligaría a distinguir entre el concepto técnico-jurídico de lesión indemnizable y el de privación de un derecho efectuado conforme al ordenamiento jurídico, ya que este último no podría originar una indemnización en caso alguno ${ }^{119}$. De esta forma, se reconduciría el instituto de la responsabilidad patrimonial a sus justos límites, entregando a otras leyes la regulación de las ayudas basadas en criterios de solidaridad ${ }^{120}$.

\section{(4.6.) Corolario}

Pues bien, cualquiera que sea la tesis que sigamos respecto de la responsabilidad patrimonial de la Administración, todas ellas tienen como denominador común la admisión de la reparación de los daños causados por actuaciones legítimas, lícitas o autorizadas por el ordenamiento jurídico: a) Garrido Falla la admite con su concepción de la teoría de la indemnización, la cual tendría lugar en el campo de la actividad adminis-

116 De Ahumada (2004) 541. Aunque admite que para poner fin a los excesos del sistema, bastaría una muy pequeña reforma al citado artículo 139.1 (actual 32.1 LRJSP), consistente en sustituir la expresión "toda lesión que sufran en cualquiera de sus bienes y derechos" por la siguiente: "toda lesión que sufran en cualquiera de sus derechos o bienes jurídicamente protegidos".

117 De Ahumada (2004) 100.

118 De Ahumada (2004) 535.

119 De Ahumada (2004) 535 y 536.

120 De Ahumada (2004) 542. 
trativa lícita ${ }^{121}$; b) Pantaleón Prieto, a través de los dańos que él denomina dańos "cuasi expropiatorios o de sacrificio", que constituyen un supuesto de funcionamiento normal de los servicios al amparo del artículo 32.1 LRJSP ${ }^{122}$; c) Mir Puigpelat, al sostener que la responsabilidad de la Administración puede nacer en ausencia de culpa o antijuridicidad ${ }^{123}$; , d) García de Enterría y De Ahumada Ramos, por el concepto de perjuicio antijurídico que postulan, predicado desde el elemento daño y no de la conducta de los órganos de la Administración.

De esta manera, dada la amplitud del sistema, la procedencia de una indemnización a favor del particular como consecuencia de intromisiones autorizadas o legítimas de la Administración, no requiere necesariamente de una previsión legislativa expresa que así la disponga, bastando que solo se configure un daño "que este no tenga el deber jurídico de soportar de acuerdo con la Ley (34.1 LRJSP)"124. Por lo tanto, no es decisivo para el nacimiento de la obligación reparatoria el hecho de que la norma que autoriza la respectiva actuación contemple en su estructura expresamente la necesidad de indemnizar al particular. Así, en aquellos supuestos en que la ley no la ha considerado, corresponderá al juez determinarla ${ }^{125}$.

\section{5) LA RESPONSABILIDAD DEL ESTADO LEGISLADOR}

La idea de que el Estado se ubica por sobre la ley y, por consiguiente, que solo es responsable por los daños que ocasione al legislar cuando una ley lo establezca expresamente, está aún latente en los diversos ordenamientos ${ }^{126}$. Más aún, existen autores que se manifiestan críticamente contra esta clase de responsabilidad"127: "definiendo la ley el ámbito de lo

121 GARRIDO (1988) 220.

122 Bajo el amparo de la antigua ley, así lo declaraba Pantaleón (1994) 247 y 248, reiterada en PANTAleón (1995) 86.

123 Mir (2002) 123.

124 Bajo el amparo de la antigua normativa, así lo declaraba Mir (2004) 20 y ss.

125 Con la evidente posibilidad de que, ante la amplitud de las normas, sea el Poder Judicial el que decida la distribución del Presupuesto General del Estado, como denuncia Pantaleón (1994) 249 y pone de manifiesto Mir (2002) 291 y ss.

126 GONZÁLEZ (2006) 59.

127 García de Enterría, Eduardo (2003) “El principio de "la responsabilidad de los poderes públicos” según el artículo 9.3 de la Constitución y la responsabilidad patrimonial del Estado legislador". Revista Española de Derecho Constitucional, No 67, pp. 15-47, pp. 41 y ss.; García de Enterría, Eduardo (2002 b) "El principio de protección de la confianza legítima como supuesto título justificativo de la responsabilidad patrimonial del Estado legislador". Revista de Administración Pública, No 159, pp. 173-206, pp. 175 y ss.; GARCía DE ENTERría (2002 a) 21 y 22. 
jurídico positivo mal puede imputarse a sus efectos un perjuicio antijurídico. Los perjuicios derivados de las leyes son cargas legales y no daños..."128.

No cabe duda que el acto de dictar una ley, promulgarla y sancionarla constituye una actividad legítima del Estado. Pero se contemplan casos en que, no obstante lo anterior, se genera una consecuencia indemnizatoria, como pasamos brevemente a comentar.

La primera vez ${ }^{129}$ que se reguló legalmente en España la posición del legislador frente a los daños producidos por la aplicación de actos legislativos, fue con la LRJPAC. En su artículo 139.3 dispuso que "las Administraciones Públicas indemnizarán a los particulares por la aplicación de actos legislativos de naturaleza no expropiatoria de derechos y que estos no tengan el deber jurídico de soportar, cuando asi se establezca en los propios actos legislativos y en los términos que especifiquen dichos actos".

Con la entrada en vigencia de la Ley 40/2015 -el 2 de octubre de 2016- la responsabilidad del Estado legislador, en principio, amplió sus horizontes, desde que el artículo 32 LRJSP, además de contemplar nuevamente la indemnización por la lesión sufrida como consecuencia de la aplicación de actos legislativos de naturaleza no expropiatoria (32.3 LRJ$\mathrm{SP})$, consideró expresamente la posibilidad de resarcir a los particulares por los daños derivados de la aplicación de una ley declarada inconstitucional como también por la aplicación de una norma contraria al Derecho de la Unión Europea (32.3.4.5.6 LRJSP) ${ }^{130}$.

Estos últimos dos títulos de imputación habían sido aceptados expresamente por la doctrina, al interpretar el enunciado "acto legislativo de naturaleza no expropiatoria” del antiguo artículo 139.3 LRJPAC, actual 32.3 LRJSP131 132, que analizaremos más adelante.

128 García de Enterría (1955) 1135 y 1136. Interesante es la cita que, sobre este punto, hace GARRIDO -defensor de la responsabilidad del Estado por esta causa, pero limitada a la previa declaración de inconstitucionalidad de la ley- a autores clásicos extranjeros, como LAFERriere y Michoud, que sostienen su mismo argumento: Garrido Falla, Fernando (1989 b). "Sobre la responsabilidad del Estado legislador". Revista de Administración Pública, No 118 , pp. 35-56, nota 2, pp. 46 y 47.

129 Quintana López, Tomás (I 994). "La responsabilidad del Estado legislador". Revista de Administración Pública, No 135, pp. 103-147, p. 123.

130 Pizarro Nevado (2016), 104-105.

131 Respecto del supuesto de ley declarada inconstitucional: González (2006) 93; Ahumada (2001) 340. Garrido es más enfático: es el único supuesto de responsabilidad del Estado legislador (GARrido (1989 b) 46 y 52).

132 En relación al supuesto de aplicación de norma contraria al Derecho de la Unión Europea: Álvarez Barbeito, Pilar (2004) "La responsabilidad patrimonial del Estado legislador: especial referencia a la vulneración del Derecho comunitario". Anuario da Facultade de Dereito da Universidade da Coruña, No 8, pp. 61-75, pp. 64 y ss.; Alonso García, María Consuelo y Leiva Ramírez, Eric (2011) "La responsabilidad del Estado por el hecho del legislador". Revista Estudios Socio-Jurídicos, vol. 13, No 2, pp. 77-106, pp. 92 y 93; RuIz (2013) 15 y ss. 


\section{(5.1.) ACTOS LEgislativos DE NATURALEZA EXPROPIATORIA Y AQUELLOS QUE NO LO SON}

El actual artículo 32.3 LRJSP dispone que “... los particulares tendrán derecho a ser indemnizados por las Administraciones Públicas de toda lesión que sufran en sus bienes y derechos como consecuencia de la aplicación de actos legislativos de naturaleza no expropiatoria de derechos que no tengan el deber jurídico de soportar cuando asi se establezca en los propios actos legislativos y en los términos que en ellos se especifiquen". Se aprecia que no existe ninguna diferencia esencial con la antigua regulación ${ }^{133}$, por lo que las controversias jurídicas surgidas allí se mantienen en la actual legislación.

Una primera lectura de dicha norma nos debería llevar a la conclusión inequívoca de que solo corresponde al legislador decidir el reconocimiento o no del derecho del particular a recibir una indemnización. Pero ello ha sido controvertido, pues se ha sostenido que también habría derecho a ella cuando una ley produzca perjuicios especiales no justificados, aunque dicha ley no se pronuncie sobre la indemnización ${ }^{134}$. Más aún, hay quienes afirman que la regla general sería el resarcimiento de los daños y que esto no tendría lugar solo si la indemnización ha sido rechazada expresamente por el legislador en la norma de la cual se deriva la lesión ${ }^{135}$.

De allí que por su no fácil interpretación y extensión ${ }^{136}$, se ha dicho que con esta disposición el legislador hizo de "aprendiz de brujo"137, incurriendo en "una cierta tautología"138. Y, más aún, la procedencia de una indemnización que traiga como causa la dictación de una ley y su

133 Pizarro Nevado (2016), 102.

134 GONZÁLEZ (2006) 71.

135 Alonso García, María Consuelo (2002) "La reciente jurisprudencia sobre la responsabilidad patrimonial del Estado legislador frente a daños derivados de leyes inconstitucionales". Revista de Administración Pública, No 157, pp. 215-240, p. 221.

136 González (2006) 87. Como gráficamente lo expone Quintana: "la redacción dada a ese precepto es de las que fácilmente pueden llegar a no satisfacer a nadie, esto es, ni a los firmes partidarios del resarcimiento por los daños causados por las leyes, ni a los que están más próximos a la tesis contraria..." (Quintana (1994) 123 y 124). También Ahumada: "las opiniones sobre el precepto ha oscilado entre la de quienes lo consideran superfluo y quienes lo consideran inconstitucional" (Ahumada Ruiz, María Ángeles (2001) "Responsabilidad patrimonial del Estado por leyes inconstitucionales (o el derecho a no ser perjudicado por una ley inconstitucional). Revista Española de Derecho Constitucional, No 62, pp. 301350, p. 307)".

137 Galán Vioque, Roberto (2001) "De la teoría a la realidad de la responsabilidad del Estado legislador”. Revista de Administración Pública, No 155, pp. 285-329, p. 310.

138 Martín Rebollo, Luis (2002) "Responsabilidad patrimonial por actos legislativos: una discutible elaboración jurisprudencial en expansión”. Actualidad Jurídica Aranzadi, No 556, BIB 2002/2101. Disponible en www.westlaw.es [fecha de visita: 5 de septiembre de 2014], pp. $1-10$, p. 1 . 
aplicación no se agotaría en actual artículo 32.3 LRJSP, sino que también podría construirse a partir del artículo $9.3 \mathrm{CE}$. En efecto, se ha postulado que una ley válida, de carácter general y abstracto, podría originar daños singulares, generando una situación de desventaja patrimonial ${ }^{139}$, por lo que no existiría ningún obstáculo para aplicar el artículo 9.3 CE a fin de determinar "la indemnización de daños producidos por leyes válidas que sirva para rellenar de contenido a la garantía constitucional de responsabilidad de los poderes públicos" 140 .

Volviendo al actual artículo 32.3 LRJSP, se acostumbra a distinguir entre actos legislativos de naturaleza expropiatoria de aquellos que no lo $\operatorname{son}^{141}$. En los primeros, la consecuencia indemnizatoria viene impuesta por el artículo $33.3 \mathrm{CE}^{142}$, que regula la expropiación. En los segundos, por el actual artículo 32.3 LRJSP ${ }^{143}$.

Si un acto legislativo de naturaleza expropiatoria contempla expresamente la concesión de una indemnización, en principio, habrá que estarse a ella en cuanto a su monto e indemnización ${ }^{144}$. Pero: ¿qué ocurre si la ley no contempla referencia alguna a la respectiva indemnización o, más aún, establece expresamente la improcedencia de la misma?

Si la ley de naturaleza expropiatoria omite toda referencia a la correspondiente indemnización, ello no impone la denegación de esta última. Solo significa que la ley ha considerado que no existen razones para establecer criterios específicos, por lo que deben aplicarse los criterios generales de expropiación forzosa a que remite el actual 34.2 LRJSP ${ }^{145}$. Así

139 Alonso García, María Consuelo (1999) La responsabilidad patrimonial del Estado legislador. Madrid: Marcial Pons, 178 p., p. 104.

140 Galán (2001) 314. Así también la jurisprudencia, como la STS de 2 de junio de 2010 (La Ley 114137/2010). En contra de este último supuesto se manifiesta GarCía de EnTERRÍa. Afirma que el principio de responsabilidad de los poderes públicos proclamado en el artículo $9.3 \mathrm{CE}$ no pretende resolver ningún problema técnico de responsabilidad patrimonial y menos aún del legislador: se refiere a algo más general, a la responsabilidad entendida como control político o constitucional. Agrega que, de existir una jurisdicción establecida en tal sentido, debería ser atribuida al Tribunal Constitucional y no a los tribunales contenciosoadministrativos (lo que califica de insólito), máxime si ni siquiera está al alcance del primero imponer una indemnización que una ley no ha previsto o que expresamente excluye, ya que importaría una clara modificación del contenido material de la ley (GARCía DE ENTERRÍA (2003) 15-47). Agrega que así se ha entendido por el TS a partir de su sentencia de 30 de noviembre de 1992 (RJ 1992/8769).

141 González (2006) 87 y ss.; Quintana (i 994) 124 y 125.

142 GonzÁlez (2006) 88; Garrido (1989 b) 51 y 22.

143 Bajo el amparo de la antigua ley, así lo manifestaba GonzÁLEZ (2006) 90 y ss.

144 Salvo el supuesto en que se fijare una indemnización que rompiera el proporcional equilibrio entre la contraprestación económica y el valor real de los bienes y derechos expropiados, que constituiría un caso de inconstitucionalidad (GonZÁLEZ (2006) 89 y 90).

145 Bajo el amparo de la antigua ley, así lo manifestaba Gonzálezz (2006) 90. 
lo entendió el Tribunal Constitucional ${ }^{146}$ y el Tribunal Supremo ${ }^{147}$ bajo el imperio de la ley antigua (LRJPAC). Ahora bien, si expresamente se establece la improcedencia de la indemnización, deberá plantearse la respectiva cuestión de inconstitucionalidad en el proceso cuyo objeto sea la impugnación del acto administrativo que, aplicando la norma de carácter expropiatoria, haya denegado la indemnización ${ }^{148}$.

\section{(5.2.) ACTOS LEGISLATIVOS DE NATURALEZA NO EXPROPIATORIA}

Tratándose de actos legislativos de naturaleza no expropiatoria y su posición frente a una obligación indemnizatoria, la problemática es similar a la antes descrita: a) si la norma legal contempla expresamente la concesión de aquella, establece las reglas conforme a las cuales debe determinarse o derechamente establece su improcedencia, habrá que estarse a la ley por aplicación estricta del actual artículo 32.3 LRJSP $^{149}$; b) si no impone indemnización alguna, no significa que ello sea improcedente. Al igual que tratándose de los actos legislativos de carácter expropiatorio, el legislador en este caso ha entendido que no concurren razones especiales que aconsejen acordarla de manera específica, quedando entregada su concesión a los criterios generales ${ }^{150}$. Ello sería así cuando el órgano jurisdiccional, indagando en la voluntad tácita o la ratio legis del legislador, deduce del acto legislativo, siquiera de un modo presunto, un propósito indemnizatorio, al constatar la producción de una lesión o daño real y efectivo en los bienes o derechos de los particulares al margen de la potestad expropiatoria ${ }^{151}$. De esta manera, la concesión de la indemnización

146 STC 28/1997, de 13 de febrero. Disponible en http://hj.tribunalconstitucional.es/ HJ/es/Resolucion/Show/3293 [fecha de visita: 4 de marzo de 2015]. En sentido similar, STC 248/2000, de 19 de octubre, fundamento jurídico $4^{\circ}$. Disponible en http:// hj.tribunalconstitucional.es/HJ/es/Resolucion/Show/4232 [fecha de visita: 4 de marzo de 2015].

147 STS de 3 de marzo de 2009 (RJ 1999/2426).

148 García de Enterría (2003) 45; González (2006) 90.

149 Bajo la vigencia de la antigua ley, así lo declaraba GonzÁLEz (2006) 91.

150 GonZÁLeZ (2006) 91. También la jurisprudencia, como lo demuestra la STS de 4 de abril de 2002 (RJ 2002/3349). CHeCA señala que la jurisprudencia, acertadamente a su juicio, no ha prestado atención a si el acto legislativo recoge o no expresamente la concesión de una indemnización, sino que atiende a si el daño consiste o no en un sacrificio especial e imprevisible para alguna persona (Checa González, Clemente (2003). "La responsabilidad patrimonial de las Administraciones Públicas por la aplicación de actos legislativos". Repertorio de Jurisprudencia Aranzadi, No 15, BIB 2003/1014. Disponible en www.westlaw.es [fecha de visita: 5 de septiembre de 2012], pp. 1-35, pp. 7 y 8).

151 En este sentido, SSTS de 23 de julio de 2010 (La Ley 114294/2010), de 18 de octubre de 2001 (La Ley 185678/2001) y de 17 de junio de 2009 (La Ley 112859/2009). 
no queda entregada a la ley sino que a la decisión de los órganos jurisdiccionales ${ }^{152}$.

Pero, ¿cuándo estamos en presencia de un acto legislativo de naturaleza no expropiatoria que haga procedente una indemnización? Antes de la dictación de la Ley 40/2015 (LRJSP), la doctrina señalaba como tales al supuesto de una ley declarada inconstitucional ${ }^{153}$, a la adopción de leyes vulneradoras del principio de confianza legítima ${ }^{154}$ y a la responsabilidad derivada del incumplimiento del Derecho de la Unión Europea ${ }^{155} 156$ 157. Con la entrada en vigencia de la LRJSP, como hemos dicho, se consagró legislativamente la indemnización por los perjuicios causados por una ley declarada inconstitucional como de aquellos ocasionados por la vulneración del Derecho Comunitario (artículo 32.3.4.5.6 LRJSP).

152 Ruiz López, Miguel Ángel (2013). "La responsabilidad patrimonial del Estado-legislador en el Derecho español". Diario La Ley, N 8151, La Ley 4873/2013. Disponible en www. laleydigital.es Disponible en www.westlaw.es [fecha de visita: 24 de marzo de 2014], pp. $1-34$, pp. 13 y 14 . En contra se manifiesta García De Enterría, quien sostiene que solo es procedente una indemnización cuando la ley lo prevé. Agrega que una posible excepción solo podría configurarse en el caso que estemos en presencia de una ley materialmente expropiatoria que no contemple indemnización: este supuesto no traería aparejado responsabilidad patrimonial alguna que reclamarse ante un tribunal ordinario, ya que la única facultad que le asistiría al juez respectivo sería plantear una cuestión de constitucionalidad ante el Tribunal Constitucional (García de Enterría, Eduardo (2005). "Sobre la responsabilidad patrimonial del Estado como autor de una ley declarada inconstitucional”. Revista de Administración Pública, No 166, pp. 99-147, pp. 117 y 118).

153 González (2006) 93; Ahumada (2001) 340. Garrido es más enfático: es el único supuesto de responsabilidad del Estado legislador (Garrido (1989 b) 46 y 52).

154 Alonso (1999) 109 y ss.; Galán (2001) 316; González Botija, Fernando (1999) "Los principios de la jurisprudencia comunitaria y su influencia en la reciente doctrina del Tribunal Supremo sobre responsabilidad del Estado legislador". Revista de Derecho Comunitario Europeo, No 6, pp. 347-374, pp. 365 y ss.

155 Álvarez Barbeito, Pilar (2004) "La responsabilidad patrimonial del Estado legislador: especial referencia a la vulneración del Derecho comunitario". Anuario da Facultade de Dereito da Universidade da Coruña, No 8, pp. 61-75, pp. 64 y ss.; Alonso García, María Consuelo y Leiva Ramírez, Eric (2011) "La responsabilidad del Estado por el hecho del legislador". Revista Estudios Socio-Jurídicos, vol. 13, No 2, pp. 77-106, pp. 92 y 93; RuIz (2013) 15 y ss.

156 Aunque se señala que, en todos los supuestos de actos legislativos no expropiatorios, resulta difícil obtener una sentencia de condena si no se establece la indemnización en el respectivo acto (Álvarez Álvarez, Henar (2012) "Responsabilidad por daños derivados de actos legislativos". Revista Práctica de Derecho de Daños, № 108/109, La Ley 16477/2012. Disponible en www.laleydigital.es [fecha de visita: 30 de julio de 2014], pp. 1-28, p. 7.

157 Sobre el particular, García de EnTERría manifiesta que "el único supuesto legítimo de una verdadera responsabilidad patrimonial por actos legislativos es cuando estos desconocen o infringen normas superiores de los ordenamientos comunitarios o internacionales dotados del principio de primacia normativa y, por tanto, con capacidad reactiva o neutralizadora de la norma inferior que puede hacer valer el mismo juez" (GARCía de EnterRía (2005) 116). 


\section{(5.2.1.) Indemnización de los perjuicios ocasionados por una ley declarada inconstitucional}

En relación a este supuesto, la letra a) del artículo 32.3 LRJSP permite exigir la reparación de los daños que se "deriven de la aplicación de una norma con rango de ley declarada inconstitucional, siempre que concurran los requisitos del apartado 4", a saber: que la norma con rango de ley sea declarada inconstitucional; que la lesión sea consecuencia de la aplicación de dicha norma; y, que "el particular haya obtenido, en cualquier instancia, sentencia firme desestimatoria de un recurso contra la actuación administrativa que ocasionó el daño, siempre que se hubiera alegado la inconstitucionalidad posteriormente declarada".

Además de lo anterior, debe verificarse el cumplimiento de lo dispuesto en los apartados 1 y 2 del artículo 32 LRJSP, por expresa mención del artículo 32.3 LRJSP, es decir, debe tratarse de un daño efectivo, evaluable económicamente, individualizado con relación a una persona o grupo de personas y antijurídico, en el sentido de que aquel no tenga el deber jurídico de soportarlo ${ }^{158}$. Respecto de la nota de antijuridicidad, se ha sostenido que ella queda evidenciada con la mera declaración de ilicitud formulada por el Tribunal Constitucional ${ }^{159}$.

La doctrina que recientemente ha comentado este supuesto, ha manifestado sus reparos respecto del requisito de la sentencia firme desestimatoria con su respectiva declaración de inconstitucionalidad. Se señala que, con esta exigencia, se restringe notablemente la posibilidad de obtener una reparación de los daños por este capítulo, ya que obliga al particular a tres cosas: agotar previamente la vía administrativa, interponer un recurso contencioso-administrativo (ya que solo así se obtiene sentencia desestimatoria) y, finalmente, alegar la inconstitucionalidad posteriormente declarada ${ }^{160}$. Con lo cual evidencia que la ausencia de impugnación administrativa y judicial impide la reclamación de los respectivos perjuicios, apartándose de la jurisprudencia del Tribunal Supremo español que se había decantado por no rechazar tal responsabilidad por el solo hecho de no haber efectuado actividad impugnatoria alguna ${ }^{161}$. Y

158 Como lo había reconocido expresamente la jurisprudencia antes de la dictación de la LRJSP: SSTS de 21 de diciembre de 2010 (La Ley 226976/2010); de 14 de septiembre de 2010 (La Ley 157594/2010); de 2 de junio de 2010 (La Ley 114137/2010).

159 SSTS de 21 de diciembre de 2010 (La Ley 226976/2010); de 14 de septiembre de 2010 (La Ley 157594/2010); de 2 de junio de 2010 (La Ley 114137/2010). En el mismo sentido, Alonso (2002) 222. En contra, Ahumada (2001) 336.

161 STS de 13 de junio de 2000. 
con la agravante de que este mismo requisito fue exigido jurisprudencialmente en un inicio para los casos de responsabilidad del Estado legislador por vulneración del Derecho comunitario, lo que fue modificado por el Tribunal de Justicia de la Unión Europea, obligando a España a rectificar tales decisiones por aquella más favorable a los intereses de los perjudica$\operatorname{dos}^{162}$.

En todo caso, debe destacarse que, bajo el imperio de la antigua LRJPAC, el Tribunal Supremo ${ }^{163}$ había decretado que era determinante la declaración expresa del Tribunal Constitucional acerca del alcance de la declaración de inconstitucionalidad que pronuncia. Así, los tribunales ordinarios podían pronunciarse sobre la existencia de responsabilidad patrimonial y fijar una indemnización en los casos de ausencia de declaración del Tribunal Constitucional; pero no podían hacerlo cuando este excluía cualquier tipo de acción revisora ${ }^{164}$. Con lo cual se puede afirmar, al mismo tiempo, que la obligación de resarcir los dańos ocasionados por una ley contraria a la Constitución está asegurada en normas de rango superior a la LRJSP, como el artículo 40.1 CE, el cual determina el alcance de las sentencias declaratorias de inconstitucionalidad en desarrollo del artículo 161.1 a) $\mathrm{CE}^{165}$.

Finalmente, el artículo 32.6 LRJSP, prescribe que "la sentencia que declare la inconstitucionalidad de la norma con rango de ley o declare el carácter de norma contraria al Derecho de la Unión Europea producirá efectos desde la fecha de su publicación en el "Boletin Oficial del Estado" o en el "Diario Oficial de la Unión Europea», según el caso, salvo que en ella se establezca otra cosa". Y ello es concordante con las decisiones adoptadas

162 Cuya última formulación se generó a partir de la STS de 17 de septiembre de 2010 (La Ley 165820/2010): Rodríguez Carbajo, José Ramón (2011). "La rectificación por el Tribunal Supremo de su doctrina sobre la responsabilidad patrimonial del Estado español derivada de las Leyes internas que infringen el Derecho comunitario". Actualidad Administrativa, No 2, tomo II, La Ley 15204/2010. Disponible en www.laleydigital.es [fecha de visita: 9 de septiembre de 2014], pp. 1-15, pp. 8 y ss.; De JuAn CASedevall, Jorge (2011) "La responsabilidad patrimonial del Estado-legislador por infracción del Derecho de la Unión en materia tributaria: la sentencia del Tribunal Supremo de 17 de septiembre de 2010". Quincena Fiscal Aranzadi, No 9, BIB 2011/548. Disponible en www.aranzadidigital.es [fecha de visita: 9 de septiembre de 2014], pp. 1-12, pp. 3 y ss.; Sesma SÁnchez, Begoña (2011) "La responsabilidad patrimonial del Estado Legislador por infracción del Derecho comunitario (comentario a la STS de 17 de octubre de 2010). Diario La Ley, No 7553, La Ley 15150/2010. Disponible en www.laleydigital.es [fecha de visita: 9 de septiembre de 2014], pp. 1-9, pp. 2 y ss.; Álvarez (2012) 20. Todo lo anterior, siguiendo los lineamientos de la jurisprudencia europea: SSTJCE de 23 de abril de 2008 (TJCE 2008/120), de 13 de marzo de 2007 (TJCE 2007/59) y de 12 de diciembre de 2006 (TJCE 2006/357).

163 STS de 18 de septiembre de 2003 (La Ley 10349/2004).

164 Ruiz (2013) 12.

165 Bajo el amparo de la LRJPAC, así lo manifestaba Ruız (2013) 13. 
con anterioridad por el Tribunal Constitucional español, que atribuyó un carácter prospectivo a los fallos que declaraban la inconstitucionalidad de una ley ${ }^{166}$, en virtud del cual los efectos de tal declaración de nulidad solo tenían eficacia hacia el futuro ${ }^{167}$. Con ello, se posibilita un camino para obtener la restitución de lo recaudado con infracción a lo establecido en la propia Constitución, negado por el efecto irretroactivo en comento y no obstante la consolidación de las situaciones jurídicas generadas en relación a la disposición anulada. Tal deber reparatorio no nace de la disposición legislativa en sí misma, sino de su aplicación al caso concreto ${ }^{168}$, permitiendo separar radicalmente la acción dirigida a obtener una compensación directamente del legislador de aquella destinada a cancelar los efectos administrativos originados por la ejecución de la norma inconstitucional $^{169}$.

\section{(5.2.2.) Indemnización de los perjuicios ocasionados por la vulneración del Derecho Comunitario}

El Tribunal de Justicia de la Comunidad Europea (TJCE) ha proclamado como "un principio inherente al sistema del Tratado" la regla según la cual los particulares tienen derecho a ser indemnizados por los dańos y perjuicios que hayan sufrido como consecuencia de una violación del derecho comunitario imputable a las autoridades nacionales ${ }^{170}$. Sentencias trascendentes que consagran esta regla son las de Francovich y Bonifaci, de 19 de noviembre de $1991^{171}$, y Brasserie du Pêcheur y Factortame, de 5 de marzo de $1996^{172}$, entre otras ${ }^{173}$.

166 Checa González, Clemente (2004) “La responsabilidad patrimonial de la administración pública con fundamento en la declaración de inconstitucionalidad de una ley”. Revista Ius et Praxis, año 10, No 1, pp. 45-75, p. 65.

167 Tendencia que se asumió por el Tribunal Constitucional desde su sentencia de 20 de febrero de 1989 (RTC 1989/45).

168 Quintana (1994) 135. Como afirma Garrido, “la ley, en cuanto tal, no produce daños concretos; estos nacen de su aplicación” (GARRIDO (1989 b) 55).

169 Alonso (2002) 224. Así, se superan los efectos del artículo 40.1 de la LOTC.

170 MacerA, Bernard-Frank (1999) "La responsabilidad estatal por violación del ordenamiento comunitario: últimos pronunciamientos del TJCE”. Revista de Administración Pública, No 149 , pp. 167-182, p. 169; Álvarez (2004) 69; Nicolás Lucas, Asunción (2005) "La incidencia en la práctica española del principio de responsabilidad patrimonial por incumplimiento del Derecho comunitario". Revista de Administración Pública, No 168, pp. 351-380, p. 376.

171 TJCE $1991 / 296$

172 TJCE $1996 / 37$

173 García de Enterría, Eduardo (1998) "El fin del caso Factortame. La responsabilidad patrimonial final del Reino Unido”. Revista de Administración Pública, No 145, pp. 117- 144, pp. 128 y ss.; Macera (i 999) 169 y ss.; Nicolás (2005) 357. 
Conforme a lo dicho, existen tres ideas fundamentales: a) los Estados miembros no pueden liberarse de responsabilidad invocando el reparto interno de competencias y responsabilidades dentro del ordenamiento interno ni alegando que la autoridad pública autora de la infracción no disponía de las competencias, conocimientos o medios necesarios; b) los jueces nacionales deben garantizar la eficacia del Derecho comunitario y la protección de los derechos que este le confiere a los particulares, la cual se extiende a la posibilidad de obtener una reparación; y, c) ante la coexistencia de ambos regímenes de responsabilidad patrimonial por actividad legislativa, sea el del Derecho interno, sea el comunitario, debe aplicarse el más favorable para el administrado ${ }^{174}$.

El fundamento de esta responsabilidad lo encontramos en el principio de primacía del ordenamiento comunitario ${ }^{175}$, sustentado en el carácter obligatorio de las normas comunitarias de Derecho derivado y el compromiso de cooperación leal en el cumplimiento de los tratados y del Derecho derivado ${ }^{176}$. También, en el efecto directo de las Directivas comunitarias, conforme al cual el contenido de estas puede ser invocado por los particulares en los litigios con la Administración, aunque no hayan sido incorporadas al ordenamiento interno o lo hayan sido de manera incorrecta $^{177}$. Y, finalmente, en el artículo 10 del Tratado CE (antiguo artículo 5), según el cual "los Estados miembros adoptarán todas las medidas generales o particulares apropiadas para asegurar el cumplimiento de las obligaciones derivadas del presente Tratado o resultantes de los actos de las instituciones de la Comunidad. Facilitarán a esta última el cumplimiento de su misión" 178 .

Estas directrices fueron recogidas expresamente por la Ley 40/2015 (LRJSP), que en la letra b) del artículo 32.3 dispuso la reparación de los daños que se "deriven de la aplicación de una norma contraria al Derecho de la Unión Europea, de acuerdo con lo dispuesto en el apartado 5”.

Por su parte, el artículo 32.5 LRJSP señala los requisitos específicos que deben reunirse: "si la lesión es consecuencia de la aplicación de una norma declarada contraria al Derecho de la Unión Europea, procederá su indemnización cuando el particular haya obtenido, en cualquier instancia, sentencia frrme desestimatoria de un recurso contra la actuación administra-

\footnotetext{
$174 \quad$ Ruiz (2013) 17 y 18.

175 Macera (1999) 170; Álvarez (2004) 66 y 67; Nicolás (2005) 358.

176 Álvarez (2004) 66.

177 Nicolás (2005) 359. Se precisa que es un efecto directo "vertical", ya que no resulta aplicable a la relaciones entre privados.

178 Macera (1999) 171; Álvarez (2004) 67; Nicolás (2005) 359.
} 
tiva que ocasionó el daño, siempre que se hubiera alegado la infracción del Derecho de la Unión Europea posteriormente declarada. Asimismo, deberán cumplirse todos los requisitos siguientes: a) La norma ha de tener por objeto conferir derechos a los particulares. b) El incumplimiento ha de estar suficientemente caracterizado. c) Ha de existir una relación de causalidad directa entre el incumplimiento de la obligación impuesta a la Administración responsable por el Derecho de la Unión Europea y el daño sufrido por los particulares". Estos mismos requisitos ya se habían formulado por la doctrina y la jurisprudencia al amparo de la antigua LRJPAC ${ }^{179}$.

Al igual que la responsabilidad del Estado legislador por aplicación de una ley declarada inconstitucional, también debe verificarse el cumplimiento de lo dispuesto en los apartados 1 y 2 del artículo 32 LRJSP, por expresa mención del artículo 32.3 LRJSP: debe tratarse de un daño efectivo, evaluable económicamente, individualizado con relación a una persona o grupo de personas y antijurídico, en el sentido de que aquel no tenga el deber jurídico de soportarlo.

De las exigencias anteriores, la que mayor dificultad presenta es la segunda, puesto que implica desentrañar el sentido de la expresión "violación suficientemente caracterizada" 180 del Derecho comunitario. Sobre este extremo, el Tribunal Supremo ${ }^{181}$ ha exigido una "inobservancia manifiesta y grave, por parte de un Estado miembro o de una Institución comunitaria, de los límites impuestos a su facultad de apreciación”, para lo cual el órgano jurisdiccional apreciará "el grado de claridad y de precisión de la norma vulnerada, la amplitud del margen de apreciación que la norma infringida deja a las autoridades nacionales o comunitarias, el carácter intencional o involuntario de la infracción cometida o del perjuicio causado, el carácter excusable o inexcusable de un eventual error de Derecho, la circunstancia de que las actitudes adoptadas por una Institución comunitaria hayan podido contribuir a la omisión, la adopción o al mantenimiento de medidas $o$ de prácticas nacionales contrarias al Derecho comunitario"182. Asimismo,

\footnotetext{
179 Cuya última formulación se generó a partir de la STS de 17 de septiembre de 2010 (La Ley 165820/2010): Rodríguez Carbajo (2011) 8 y ss.; De Juan Casedevall (2011) 3 y ss.; Sesma Sánchez (2011) 2 y ss.; Álvvarez (2012) 20. Todo lo anterior, siguiendo los lineamientos de la jurisprudencia europea: SSTJCE de 23 de abril de 2008 (TJCE 2008/120), de 13 de marzo de 2007 (TJCE 2007/59) y de 12 de diciembre de 2006 (TJCE 2006/357). Terminología que también se ha criticado, desde que ella emana de la locución inglesa "sufficiently serious breach", cuyo traducción más acorde al sentido de la institución sería "violación suficientemente grave" (De JuAN (2011) 5).

181 STS de 20 de noviembre de 2013 (La Ley 190831/2013) así como la jurisprudencia que en ella se indica.

182 También Álvarez (2004) 73; De Juan (2011) 5; Nicolás (2005) 362 y 363; Álvarez (2012) 22 y 23.
} 
se declara concurrente este requisito cuando la infracción ha perdurado a pesar de haberse dictado una sentencia en la que se declara la existencia del incumplimiento reprochado, de una sentencia prejudicial o de una jurisprudencia reiterada del Tribunal de Justicia en la materia de las que resulte el carácter de infracción del comportamiento controvertido ${ }^{183}$.

Dado que la nueva LRJSP positivizó una práctica constante de los tribunales superiores españoles, no deberíamos tener mayores novedades sobre su aplicación, debiendo mantenerse sus extremos principales en lo relativo a la extensión de la reparación, los principios que lo informan y la clase de responsabilidad, de lo cual pasamos a dar cuenta.

En esta clase de indemnizaciones, la reparación que se otorga consiste en la devolución de la cantidad indebidamente ingresada (acción de restitución) ${ }^{184}$, o bien, en una "compensación pecuniaria equitativa” 185 , debiendo respetarse los principios de equivalencia y de efectividad ${ }^{186}$.

Conforme al principio de equivalencia, los Estados miembros quedan impedidos de aplicar a esta clase de reclamaciones trámites o requisitos más gravosos que aquellos que se susciten con ocasión de decisiones o inactividades contrarias al Derecho interno ${ }^{187}$, tales como los criterios que permitan determinar la cuantía de la indemnización ${ }^{188}$, estatuto aplicable $^{189}$, recursos y plazos ${ }^{190}$, entre otros. En virtud de este principio, el Tribunal Supremo tuvo que modificar su doctrina anterior, como lo pone de manifiesto el No 48 del Fundamento de Derecho noveno de la sentencia de 17 de septiembre de $2010^{191}$.

\footnotetext{
183 También Álvarez (2004) 73 y 74.

I 84 De JuAn (2011) 6.

185 STJCE de 21 de febrero de 2008 (BIB 2008/29).

186 Áluarez (2012) 21; De Juan (2011) 7.
}

187 Álvarez (2012) 21. En sentido similar, Falcón y Tella, Ramón (2010). "La responsabilidad patrimonial del Estado por infracción del ordenamiento comunitario: la STJ 26 enero 2010 (Asunto Transportes Urbanos) y sus consecuencias". Quincena Fiscal Aranzadi, No 4, BIB 2010/175. Disponible en www.aranzadidigital.es [fecha de visita: 9 de septiembre de 2014], pp. $1-4$, pp. 1 y 2.

188 De JuAn (2011) 7.

189 RuIZ (2013) 18.

190 Calderón González, Jesús María (2013) “La responsabilidad patrimonial del Estado en los supuestos de contradicción con el Derecho Comunitario. Presupuestos de su aplicación”. Quincena Fiscal Aranzadi, No 9, BIB 2013/917. Disponible en www.aranzadidigital.es [fecha de visita: 9 de septiembre de 2014], pp. 1-31, pp. 9 a 11; Pedraz Calvo, Mercedes (2011) "Jurisprudencia del Tribunal Supremo en materia de responsabilidad patrimonial por incumplimiento del Derecho de la Unión Europea”. Gaceta Jurídica de la Unión Europea $y$ de la Competencia, No 19, La Ley 15760/2010. Disponible en www.laleydigital.es [fecha de visita: 9 de septiembre de 2014], pp. 1-27, p. 20. 
El principio de efectividad impide a los Estados miembros de la Unión establecer regulaciones que hagan prácticamente imposible o excesivamente difícil la reparación que se solicita ${ }^{192}$. Así, se ha resuelto que "la exclusión total, en concepto de daño reparable, del lucro cesante no puede admitirse en caso de violación del Derecho comunitario, ya que, especialmente en materia de litigios de carácter económico o mercantil, tal exclusión total del lucro cesante puede imposibilitar en la práctica la reparación del daño..."193. También, que el derecho a una tutela judicial efectiva se opone a una normativa nacional que se interpreta en el sentido de que los miembros de una unión temporal de empresas, licitadora en un procedimiento de adjudicación de un contrato público, sean privados de la posibilidad de solicitar, a título individual, la reparación del perjuicio que hayan sufrido de forma individual a raíz de una resolución adoptada por una autoridad distinta del poder adjudicador, que forme parte de dicho procedimiento de conformidad con las normas nacionales aplicables y que pueda influir en su desarrollo ${ }^{194}$.

Finalmente, se trata de una responsabilidad objetiva ${ }^{195}$, puesto que la procedencia de la indemnización no queda supeditada al requisito de la culpa, desde que, de lo contrario, se pondría en entredicho el derecho a la debida reparación que tiene su fundamento en el ordenamiento jurídico comunitario ${ }^{196}$. Por lo tanto, lo que da nacimiento a la obligación reparatoria es la existencia de un nexo causal entre el incumplimiento del Derecho comunitario y los perjuicios causados a los particulares ${ }^{197}$.

\section{(5.2.3.) Indemnización de los perjuicios ocasionados por la vulneración del principio de confianza legítima}

Este título de imputación no fue recogido en la Ley 40/2015 (LRJ$\mathrm{SP})$, lo que no implica necesariamente su descarte inmediato, desde que la doctrina lo obtenía de la interpretación del enunciado "acto legislativo de naturaleza no expropiatoria" del antiguo artículo 139.3 LRJPAC y mantenido en el actual artículo 32.3 LRJSP ${ }^{198}$.

\footnotetext{
192 DE JUAN (2011) 7.

193 STJCE de 13 de julio de 2006 (La Ley 87883/2006).

194 STJCE de 6 de mayo de 2010 (La Ley 34332/2010).

195 Macera (1999) 174; Álvarez (2004) 72; Nicolás (2005)360; Álvarez (2012) 23.

196 En este sentido, STJCE de 5 de marzo de 1996 (TJCE 1996/37).

197 Macera (I999) 174. SSTJCE de 23 de abril de 2008 (TJCE 2008/120), de 13 de marzo de 2007 (TJCE 2007/59) y de 12 de diciembre de 2006 (TJCE 2006/357), que detallan los presupuestos de la responsabilidad por infracción al Derecho comunitario. 
Con respecto a la indemnización de los perjuicios ocasionados por la vulneración del principio de confianza legítima, se ha propiciado su reparación cuando el legislador introduce cambios normativos que no son razonablemente previsibles y que no pudieron entrar en el cálculo de quienes adecuaron su conducta económica a una situación jurídica que consideraban estable, viéndose perjudicados por el cambio de regulación ${ }^{199}$.

Esta consecuencia reparatoria tenía su base normativa en el artículo 3 de la antigua LRJPAC, mantenido en la letra e) del actual artículo 3.1 LRJSP, que obliga a las Administraciones Públicas a respetar en su actuación el principio de "buena fe, confianza legítima y lealtad institucional", el cual sirve, asimismo, como eje sobre el que gira el examen de las circunstancias concurrentes en cada caso para determinar si hay o no justificación para soportar el daño causado ${ }^{200}$.

Este principio tuvo consagración expresa a partir de la sentencia del Tribunal Supremo de 28 de mayo de $1997^{201}$, que reconoció a las sentencias de la misma magistratura de 5 de marzo de $1993^{202}$ y de 27 de junio de $1994^{203}$ como las decisiones precursoras que establecieron la responsabilidad patrimonial del Estado legislador fundada en la vulneración del principio de confianza legítima. Tales resoluciones -que si bien hacían alusión a los principios de buena fe y seguridad jurídica- acogieron las pretensiones indemnizatorias de sociedades pesqueras que habían efectuado fuertes inversiones en desarrollo y ejecución de acciones de fomento programadas por el gobierno y materializadas, entre otras disposiciones, en el Decreto 8-10-1976 y Real Decreto 30-4-1985, en virtud de las cuales crearon empresas pesqueras conjuntas en ponderación de los concretos beneficios que se reconocían a los armadores españoles (créditos a la exportación de buques de pesca en explotación, cobertura de los riesgos de inversiones y la importación de pescado con exención del pago de derechos arancelarios y compensatorios variables), acomodando su actividad a la política de fomento del gobierno. Pues bien, como consecuencia de la aprobación de la Ley de Adhesión a la Comunidad Europea suscrito por el Reino de España y promovido por el gobierno, resultaron eliminados, aunque fuera progresivamente, los cupos exentos de arancel, que, según parece, era el mayor beneficio para las empresas pesqueras españolas.

\footnotetext{
199 Ahumada (2001) 310.

200 Állvarez Állvarez (2012) 16.

201 RJ 1997/5943; González Botija (1999) 366.

202 RJ $1993 / 1623$.

203 RJ 1994/4981.
} 
Como consecuencia de ello, se hizo lugar a la respectiva indemnización por "la existencia de derechos o al menos intereses patrimoniales legitimos, cuyo sacrificio particular se impuso por las determinaciones que hemos relatado, sin que las respectivas sociedades tengan el deber juridico de soportarlo, y además porque concurren cuantos requisitos exige nuestro ordenamiento para dar lugar a la responsabilidad patrimonial del Estado, esto es daño, no causado por fuerza mayor, efectivo, evaluable económicamente e individualizado, que es consecuencia directa (nexo causal) de los concretos actos que se aducen y que hemos examinado como determinantes de la lesión patrimonial..."204.

Más recientemente se han concedido esta clase de indemnizaciones por las delimitaciones impuestas por leyes de Comunidades Autónomas a las facultades dominicales de los particulares. Así, se estimó vulnerado el principio de confianza legítima de quien, actuando de buena fe y conforme a la legislación entonces vigente, realizó gastos destinados a la terminación de un proyecto urbanístico cuya viabilidad había sido proclamada bajo el amparo de la disposición transitoria de una ley y que fue eliminada por la nueva redacción de aquella por una nueva ley ${ }^{205}$.

Se ha afirmado que la virtualidad de este principio puede comportar la anulación y, cuando menos, obliga a responder en el marco comunitario de la alteración de las circunstancias económicas habituales y estables, generadoras de esperanzas fundadas de mantenimiento ${ }^{206}$.

Debe consignarse que la invocación de este principio no puede impedir las nuevas regulaciones hacia el futuro o servir de medio para mantener una determinada situación beneficiosa ${ }^{207}$. Asimismo, si lo que se impugna es el contenido de una norma, no puede utilizarse la vía de la responsabilidad patrimonial de la Administración para tal fin, sino que habrá que plantear ante el Tribunal Constitucional el respectivo recurso o cuestión de inconstitucionalidad ${ }^{208}$.

En todo caso, el título indemnizatorio en comento se trata de un supuesto excepcional, como lo reconoce la doctrina que lo acepta ${ }^{209}$ y la jurisprudencia, que ha señalado que se excluye el derecho a la reparación y se da "prevalencia a la potestad de innovación normativa, con el fin de que no queden petrificadas regulaciones al margen de la evolución real de los in-

\footnotetext{
204 Fundamento de Derecho 3o de las SSTS de 5 de marzo de 1993 y de 27 de junio de 1994, ya citadas.

205 STS de 23 de julio de 2010 (La Ley 114294/2010).

206 Fundamento de Derecho 6º de la STS de 28 de mayo de 1997, ya citada.

207 Como lo resolvió la STS de 16 de diciembre de 2008 (La Ley 193779/2008).

208 ÁllVArez (2012) 17.

209 Alonso y Leiva (2011) 89.
} 
tereses generales y del ejercicio de las facultades de apreciación de los órganos llamados a velar por ellos, según las competencias reconocidas por la Constitución y la ley" ${ }^{210}$. Además, este supuesto reparatorio generalmente será desestimado cuando la ley cuestionada contemple la aplicación temporal escalonada de la norma o las respectivas medidas compensatorias ${ }^{211}$.

Particularmente crítico de este título indemnizatorio se manifiesta García de Enterría. Señala que solo si el principio de protección de la confianza tuviese rango constitucional podría invocarse su infracción como causa de responsabilidad del legislador ${ }^{212}$, lo que él rechaza, no pudiendo estimarse que tenga tal jerarquía por ser una manifestación del principio de seguridad jurídica del artículo $9.3 \mathrm{CE}^{213}$. Agrega que la protección de los derechos o intereses de los particulares mediante el mantenimiento de la situación jurídica existente, descartando cualquier intento de innovación, es una nota característica del orden antiguo o posmoderno que fue abandonado por la nueva configuración del legislador que emergió de las revoluciones democráticas ${ }^{214}$. Señala que, a diferencia de las situaciones jurídicas subjetivas o individuales, las situaciones jurídicas generales, impersonales y objetivas, creadas por Leyes o Reglamentos igualmente generales, impersonales y objetivos, no tienen ninguna posibilidad de perseverar ante el cambio de la Ley o el Reglamento que las ha creado y que pueden, con la misma potestad, sustituirlas por una nueva situación general y objetiva, frente a lo cual ninguno de los incluidos en la situación legal o reglamentaria anterior tiene absolutamente ningún derecho $^{215}$. Cita jurisprudencias del Tribunal Constitucional y Tribunal Supremo que avalan su tesis ${ }^{216}$.

\section{(5.3.) CALIFICACIÓN DE UNA LEY DE NATURALEZA EXPROPIATORIA Y COROLARIO}

Cabe agregar, en todo caso, que la circunstancia de que una ley sea o no de carácter expropiatorio no depende de la calificación que haga el

\footnotetext{
210 Entre otras, STS de 16 de diciembre de 2008 (La Ley 193779/2008).

211 GonzÁlez (1999) 369 y ss.; Alonso y Leiva (2011) 89.

212 García de Enterría (2002 b) 175 y ss.

213 García de Enterría (2002 b) 176.

214 García de Enterría (2002 b) 189.

215 García de Enterría (2002 b) 197 y 198.

216 Entre las que se destaca la STS de 30 de noviembre de 1992 (RJ 1992/9393), que se pronunció sobre la supresión del llamado "turno de consorte" para los traslados en el Cuerpo de Profesores de Enseñanza General Básica.
} 
legislador, sino que se desprende de su propia naturaleza. De lo contrario, se burlaría la garantía constitucional del derecho de propiedad ${ }^{217}$.

Con todo lo antes dicho y al igual que la responsabilidad patrimonial de la Administración, la procedencia de una indemnización a favor del particular como consecuencia de intromisiones autorizadas o legítimas del legislador no requiere de una previsión legislativa expresa que así la disponga. Por lo tanto, no es decisivo para el nacimiento de la obligación reparatoria el hecho de que la norma que autoriza la respectiva actuación contemple en su estructura expresamente la necesidad de indemnizar al particular. Así, en aquellos supuestos en que la ley no la ha considerado, corresponderá al juez determinarla.

\section{CONCLUSIONES}

1.- Por regla general, la única tesis que no tiene reparos respecto de la procedencia de una reparación, es aquella que propicia que la indemnización de Derecho público por actuación ajustada a Derecho solo procede en aquellos casos en que la ley expresamente la ha previsto.

2.- Este principio se ha visto ampliamente desbordado en el sistema español, en que en las hipótesis de responsabilidad patrimonial de la Administración y del Estado legislador, la existencia de una ley que contemple la correspondiente indemnización no es decisiva para conceder una reparación pecuniaria en los eventos de actuaciones completamente ajustadas a Derecho. Su nacimiento queda sujeto a la decisión de los órganos jurisdiccionales.

\section{BIBLIOGRAFÍA}

Ahumada Ruiz, María Ángeles (2001) "Responsabilidad patrimonial del Estado por leyes inconstitucionales (o el derecho a no ser perjudicado por una ley inconstitucional)". Revista Española de Derecho Constitucional, No 62, pp. 301-350.

217 GonZÁlez (2006) 88. Quintana señala que “... la vocación expropiatoria que pueden tener las disposiciones con rango de Ley exige el respeto de las garantías básicas del derecho de propiedad, y su exclusión determina la inconstitucionalidad; consecuentemente también con este planteamiento, toda lesión patrimonial derivada de la aplicación de una Ley de naturaleza no expropiatoria es el campo de la llamada responsabilidad patrimonial del Estado legislador... (Quintana López (1994) 125 y 126)”. 
Alessi, Renato (1939) La responsabilità della pubblica amministrazione, vol. I. Milán: Giuffrè, 275 pp.

Alonso García, María Consuelo (1999) La responsabilidad patrimonial del Estado legislador. Madrid: Marcial Pons, 178 pp.

Alonso García, María Consuelo (2002) "La reciente jurisprudencia sobre la responsabilidad patrimonial del Estado legislador frente a daños derivados de leyes inconstitucionales". Revista de Administración Pública, No 157, pp. 215-240.

Alonso García, María Consuelo y Leiva Ramírez, Eric (2011) "La responsabilidad del Estado por el hecho del legislador". Revista Estudios Socio-Jurídicos, vol. 13, No 2, pp. 77-106.

Álvarez Álvarez, Henar (2012) "Responsabilidad por daños derivados de actos legislativos". Revista Práctica de Derecho de Daños, No 108/109, La Ley 16477/2012. Disponible en www.laleydigital.es [fecha de visita: 30 de julio de 2014], pp. 1-28.

Álvarez Barbeito, Pilar (2004) "La responsabilidad patrimonial del Estado legislador: especial referencia a la vulneración del Derecho comunitario". Anuario da Facultade de Dereito da Universidade da Coruña, No 8, pp. 61-75.

Bello Janeiro, Domingo (2006) "La responsabilidad patrimonial de la Administración”. Revista Práctica de Derecho de Daños, No 37, La Ley 517/2006. Disponible en www.laleydigital.es [fecha de visita: 4 de agosto de 2012], p. 1-14.

Berberoff Ayuda, Dimitry y Sospedra Nava, Francisco (2006) Fundamentos dogmáticos de la responsabilidad patrimonial de la Administración en la jurisprudencia, vol. II. Madrid: Consejo General del Poder Judicial-Fundación Wellington, 463 pp.

Blasco Esteve, Andrés (1981) La responsabilidad de la Administración por actos administrativos. Madrid: Civitas, $243 \mathrm{pp}$.

Calderón González, Jesús María (2013) “La responsabilidad patrimonial del Estado en los supuestos de contradicción con el Derecho Comunitario. Presupuestos de su aplicación”. Quincena Fiscal Aranzadi, No 9, BIB 2013/917. Disponible en www. aranzadidigital.es [fecha de visita: 9 de septiembre de 2014], pp. $1-31$.

Checa González, Clemente (2003) "La responsabilidad patrimonial de las Administraciones Públicas por la aplicación de actos legislativos". Repertorio de Jurisprudencia Aranzadi, No 15, BIB 2003/1014. Disponible en www.westlaw.es [fecha de visita: 5 de septiembre de 2012], pp. 1-35.

Checa González, Clemente (2004) "La responsabilidad patrimonial de la administración pública con fundamento en la declaración de 
inconstitucionalidad de una ley". Revista Ius et Praxis, ańo 10, No 1 , pp. 45-75.

Cordero Quinzacara, Eduardo (2006) "La dogmática constitucional de la propiedad en el Derecho chileno". Revista de Derecho (Valdivia), vol. XIX, N 1 , pp. 125-148.

Cordero Vega, Luis (2011) "La Corte Suprema y la responsabilidad del Estado”. El Mercurio Legal, 20 de septiembre de 2011. Disponible en www.elmercurio.com [fecha de visita: 16 de junio de 2015].

Cordero Vega, Luis (2012) "Las vacas locas y la responsabilidad del Estado por acto lícito". El Mercurio Legal, 22 de noviembre de 2012. Disponible en www.elmercurio.com [fecha de visita: 16 de junio de 2015].

De Ahumada Ramos, Francisco Javier (2004) La responsabilidad patrimonial de las Administraciones públicas. 2a edición. Cizur Menor: Thomson Aranzadi, 587 pp.

De Juan Casedevall, Jorge (2011) "La responsabilidad patrimonial del Estado-legislador por infracción del Derecho de la Unión en materia tributaria: la sentencia del Tribunal Supremo de 17 de septiembre de 2010”. Quincena Fiscal Aranzadi, No 9, BIB 2011/548. Disponible en www.aranzadidigital.es [fecha de visita: 9 de septiembre de 2014], pp. 1-12.

Falcón y Tella, Ramón (2010) "La responsabilidad patrimonial del Estado por infracción del ordenamiento comunitario: la STJ 26 enero 2010 (Asunto Transportes Urbanos) y sus consecuencias". Quincena Fiscal Aranzadi, No 4, BIB 2010/175. Disponible en www. aranzadidigital.es [fecha de visita: 9 de septiembre de 2014], pp. 1-4.

Fleiner, Fritz (1933) Instituciones de Derecho administrativo. Traducción de la $8^{a}$ edición alemana por Sabino A. Gendin. Barcelona-MadridBuenos Aires: Editorial Labor S.A., 362 pp.

Forsthoff, Ernst (1958) Tratado de Derecho administrativo. Madrid: Instituto de Estudios Políticos, 768 pp.

Galán Vioque, Roberto (2001) "De la teoría a la realidad de la responsabilidad del Estado legislador". Revista de Administración Pública, No 155, pp. 285-329.

García de Enterría, Eduardo (1955) "Potestad expropiatoria y garantía patrimonial en la nueva Ley de Expropiación Forzosa". Anuario de Derecho Civil. Vol. 8, N 5, pp. 1023-1166.

García de Enterría, Eduardo (i998) "El fin del caso Factortame. La responsabilidad patrimonial final del Reino Unido". Revista de Administración Pública, No 145, pp. 117- 144.

García de Enterría, Eduardo (2002 a) "Prólogo" a la obra de Mir Puigrelat, Oriol (2002). La responsabilidad patrimonial de la Administración. Hacia un nuevo sistema. Madrid: Civitas, pp. 19-26. 
García de Enterría, Eduardo (2002 b) "El principio de protección de la confianza legítima como supuesto título justificativo de la responsabilidad patrimonial del Estado legislador". Revista de Administración Pública, No 159, pp. 173-206.

García De Enterría, Eduardo (2003) "El principio de "la responsabilidad de los poderes públicos" según el artículo 9.3 de la Constitución y la responsabilidad patrimonial del Estado legislador". Revista Española de Derecho Constitucional, No 67, pp. 15-47.

García De Enterría, Eduardo (2005) "Sobre la responsabilidad patrimonial del Estado como autor de una ley declarada inconstitucional". Revista de Administración Pública, No 166, pp. 99147.

Garrido Falla, Fernando (1952) "La teoría de la indemnización en Derecho público". En Estudios dedicados al profesor Gascón y Marín. Madrid: Instituto de Estudios de Administración Local, pp. 411443.

Garrido Falla, Fernando (1988). Tratado de Derecho Administrativo, vol. II. $8^{\mathrm{a}}$ edición. Madrid, Tecnos, $420 \mathrm{pp}$.

Garrido Falla, Fernando (1989 a) "La constitucionalización de la responsabilidad patrimonial del Estado". Revista de Administración Pública, $\mathrm{N}^{\circ} 119$, pp. 7-48.

Garrido Falla, Fernando (1989 b) "Sobre la responsabilidad del Estado legislador”. Revista de Administración Pública, No 118, pp. 35-56.

Garrido Falla, Fernando (1997) "Los límites de la responsabilidad patrimonial: una propuesta de reforma legislativa". Revista Española de Derecho Administrativo, No 94, pp. 173-188.

Garrido Falla, Fernando, Palomar Olmeda, Alberto y Losada González, Herminio (2006) Tratado de Derecho Administrativo. 12a edición, vol. II. Madrid: Tecnos, 592 pp.

González Botija, Fernando (1999) "Los principios de la jurisprudencia comunitaria y su influencia en la reciente doctrina del Tribunal Supremo sobre responsabilidad del Estado legislador". Revista de Derecho Comunitario Europeo, No 6, pp. 347-374.

González Pérez, Jesús (2006) Responsabilidad patrimonial de las Administraciones Públicas. $4^{a}$ edición. Cizur Menor: Thomson Civitas, 734 pp.

González-Varas, Santiago (2012) Tratado de Derecho administrativo. 2a edición. Tomo I. Cizur Menor: Civitas-Thomson Reuters, 856 pp.

Gozálbez Pequeño, Humberto (director) (2016) La nueva Ley del Procedimiento Administrativo Común. Madrid: El Consultor de los Ayuntamientos-Wolters Kluwer.

Leguina Villa, Jesús (1983) La responsabilidad civil de la Administración Pública. 2a edición. Madrid: Tecnos, 374 pp. 
Marienhoff, Miguel (1992) "Responsabilidad del Estado por sus actos lícitos". En U. Complutense (editor). En U. Complutense (editor). Actualidad y perspectivas del Derecho público a fines del siglo XX. Homenaje al profesor Garrido Falla. Vol. II. Madrid: Editorial Complutense, pp. 1247-1262.

Macera, Bernard-Frank (1999) "La responsabilidad estatal por violación del ordenamiento comunitario: últimos pronunciamientos del TJCE”. Revista de Administración Pública, No 149, pp. 167-182.

Martín Rebollo, Luis (2002) "Responsabilidad patrimonial por actos legislativos: una discutible elaboración jurisprudencial en expansión”. Actualidad Jurídica Aranzadi, No 556, BIB 2002/2101. Disponible en www.westlaw.es [fecha de visita: 5 de septiembre de 2014], pp. 1-10.

Mir Puigpelat, Oriol (2002) La responsabilidad patrimonial de la Administración. Hacia un nuevo sistema. Madrid: Civitas, 371 pp.

Mir Puigpelat, Oriol (2004) "El sistema español de responsabilidad patrimonial de la Administración: una visión crítica”. En Marín González, Juan Carlos (compilación y estudio introductorio). La responsabilidad patrimonial del Estado. Ciudad de México: Editorial Porrúa-Itam, pp. 1-51.

Moreno Molina, José Antonio y Magán Perales, José María (2005) La responsabilidad patrimonial de las Administraciones Públicas y, en especial, de las Corporaciones Locales. Madrid: Editorial El Consultor de los Ayuntamientos y de los Juzgados, 663 pp.

Nicolás Lucas, Asunción (2005) "La incidencia en la práctica española del principio de responsabilidad patrimonial por incumplimiento del Derecho comunitario". Revista de Administración Pública, No 168, pp. 351-380.

Nieto, Alejandro (1962) "Evolución expansiva del concepto de la expropiación forzosa”. Revista de Administración Pública, pp. 67-124.

Oelckers Camus, Osvaldo (1987) "Fundamentos indemnizatorios en razón del acto administrativo lícito que cause daño en el patrimonio del administrado". Revista de Derecho de la Pontificia U. Católica de Valparaiso, $\mathrm{N}^{\circ} 11$, pp. 67-77.

Pantaleón Prieto, Fernando (1994) "Los anteojos del civilista: hacia una revisión del régimen de responsabilidad patrimonial de las Administraciones públicas". Revista Documentación Administrativa, No 237-238, pp. 239-254.

Pantaleón Prieto, Fernando (1995) Responsabilidad médica y responsabilidad de la Administración (hacia una revisión del sistema de responsabilidad patrimonial de las Administraciones Públicas). Madrid: Civitas, 91 pp. 
Pedraz Calvo, Mercedes (2011) "Jurisprudencia del Tribunal Supremo en materia de responsabilidad patrimonial por incumplimiento del Derecho de la Unión Europea". Gaceta Jurídica de la Unión Europea y de la Competencia, No 19, La Ley 15760/2010. Disponible en www. laleydigital.es [fecha de visita: 9 de septiembre de 2014], pp. 1-27.

Pizarro Nevado, Rafael (2016) "Capítulo I. Disposiciones generales, principios de actuación y funcionamiento del sector público". En Gozálbez Pequeño, Humberto (director). El nuevo régimen jurídico del sector público. Madrid: El Consultor de los AyuntamientosWolters Kluwer, pp. 15-152.

Quintana López, Tomás (1994) "La responsabilidad del Estado legislador". Revista de Administración Pública, No 135, pp. 103-147.

Quintanilla Pérez, Álvaro (2004) "Corte Suprema en caso Lolco: no hay responsabilidad estatal por actos lícitos. El ocaso de la doctrina Galletué". Revista de Derecho del Consejo de Defensa del Estado, ${ }^{\circ}$ 12, pp. 41-54.

Rodríguez Carbajo, José Ramón (2010) “La antijuridicidad del daño como requisito de la responsabilidad patrimonial de la Administración". Actualidad Administrativa, No 7, La Ley 1812/2010. Disponible en www.laleydigital.es [fecha de visita: 25 de julio de 2012], pp. 1-8.

Rodríguez Carbajo, José Ramón (2011) "La rectificación por el Tribunal Supremo de su doctrina sobre la responsabilidad patrimonial del Estado español derivada de las Leyes internas que infringen el Derecho comunitario". Actualidad Administrativa, No 2, tomo II, La Ley 15204/2010. Disponible en www.laleydigital.es [fecha de visita: 9 de septiembre de 2014], pp. 1-15.

Ruiz López, Miguel Ángel (2013) "La responsabilidad patrimonial del Estado-legislador en el Derecho español”. Diario La Ley, № 8151, La Ley 4873/2013. Disponible en www.westlaw.es [fecha de visita: 24 de marzo de 2014], pp. 1-34, pp. 13 y 14.

Sesma Sánchez, Begoña (2011) "La responsabilidad patrimonial del Estado Legislador por infracción del Derecho comunitario (comentario a la STS de 17 de octubre de 2010). Diario La Ley, No 7553, La Ley 15150/2010. Disponible en www.laleydigital.es [fecha de visita: 9 de septiembre de 2014], pp. 1-9. 